\title{
Wastes From Selected Activities in Two Light-Water Reactor Fuel Cycles
}
C. R. Palmer
O. F. Hill

July 1980

Prepared for the U.S. Department of Energy under Contract DE-AC06-76RLO 1830

Pacific Northwest Laboratory

Operated for the U.S. Department of Energy by Battelle Memorial Institute 
NOTICE

This report was prepared as an account of work sponsored bv the United States Covernment. Neither the United States nor the Department of Energy, not any of their employees, not any of their contractors; subcontractors. or their emplovees. makes any warranty, express or implied, or assumes any legal liability or responsibility for the accuracy. completeness or usefulness of any information, apparatus, product or process disclosed, or represents that its use would not iniringe privately owned rights.

The views, opinions and conclustons contained in this report are those of the contractor and do not necessarily tepresent those of the United States Government or the United States Department of Energy.

\author{
PACIFIC NORTHWEST LABORATORY \\ operated by \\ BATTELLE \\ for the \\ UNITED STATES DEPARTMENT OF ENERCY \\ Under Contract DE-ACO6-76RLO 1830
}

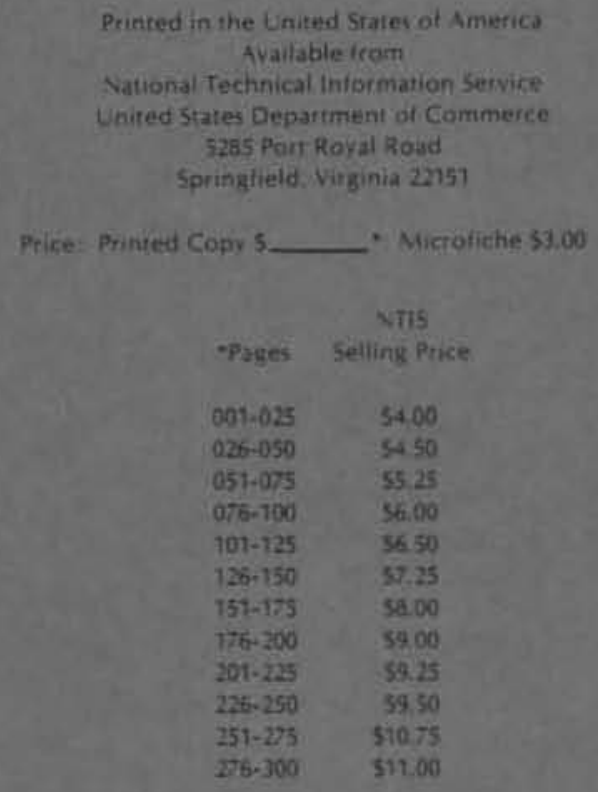


PNL-3425

UC -70

33679000544850

WASTES FROM SELECTED ACTIVITIES IN

TWO LIGHT-WATER REACTOR FUEL CYCLES

C. R. Palmer

O. F. Hill

July 1980

Prepared for

the U.S. Department of Energy under Contract DE-AC06-76RLO 1830

Pacific Northwest Laboratory

Richland, Washington 99352 


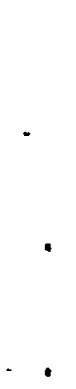




\section{CONTENTS}

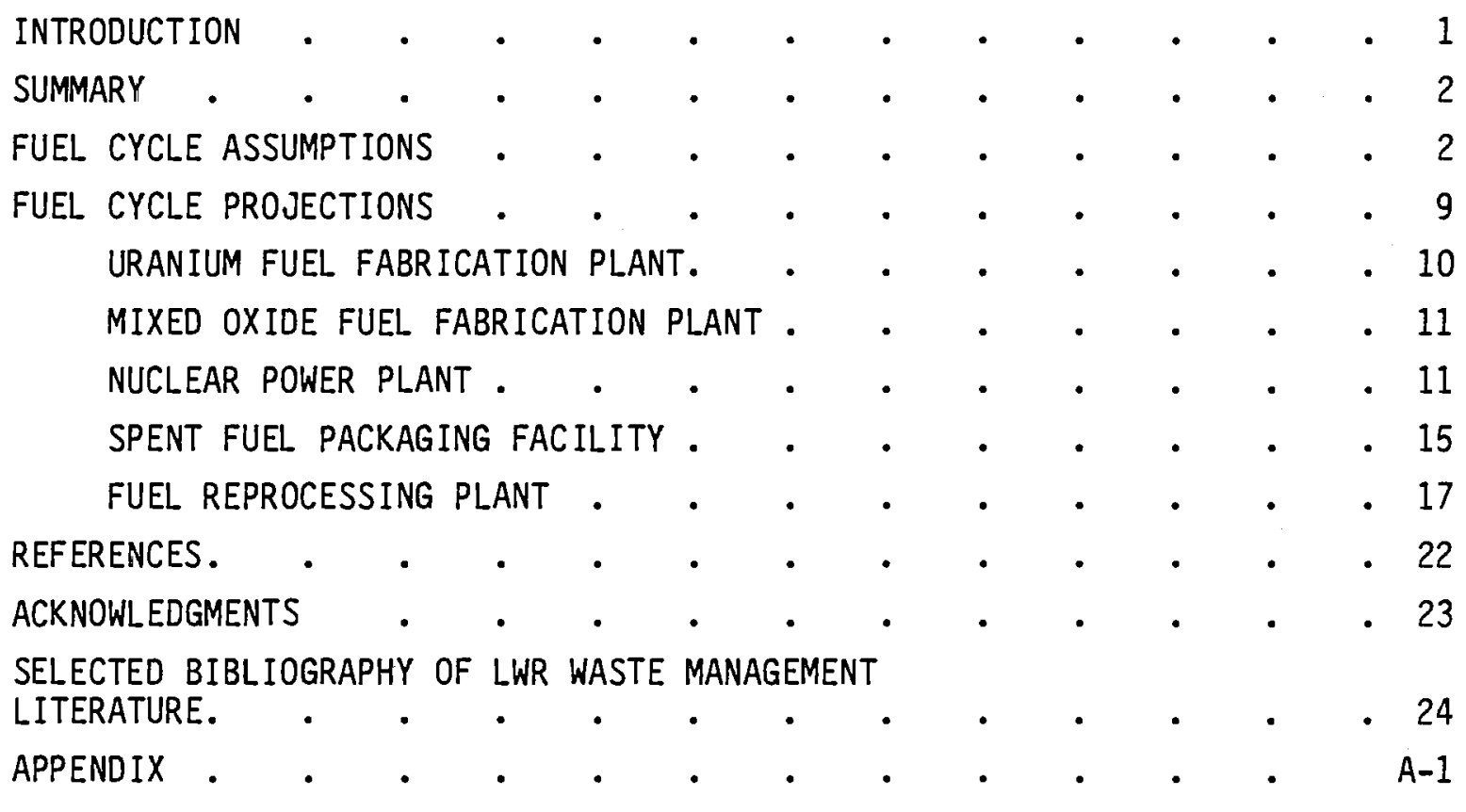




\section{FIGURES}

1 Strategy 1 LWR Once-Through Heavy Element Flow Sheet per GWe yr.

2 Strategy 2 LWR with U-Pu Recycle Heavy Element Flow Sheet per GWe yr

\section{TABLES}

1 Surmary of Waste Volumes for Reference LWR Fuel Cycles per GWe.yr.

2 Fuel Element Fabrication Wastes for Reference LWR Fuel Cycles per GWe.yr.

3 Reactor Wastes for Reference LWR Fuel Cycles per GWe.yr

4 Unreprocessed Spent Fuel for Reference LWR Fuel Cycles per GWe.yr.

5 Reprocessing Wastes for Reference LWR Fuel Cycles per GWe.yr

6 Characteristics of the Reference Fuel Cycle Facilities

7 Estimated Waste Volumes and Activities from the Reference Uranium Fuel Fabrication Plant . • . . . 12

8 Estimated Waste Volumes and Activities from the Reference Mixed-oxide Fuel Fabrication Plant . . . . 13

9 Estimated Waste Volumes and Activities from the Reference Nuclear Power Plant . . . . . . 16

10 Estimated Waste Volumes and Activities from the Reference Spent Fuel Packaging Facility

11 Estimated Waste Volumes and Activities from the Reference Fuel Reprocessing Plant

12 Sumary of Operating Wastes from the Reference Fuel Reprocessing Plant by Package Dose Rate

A-1 Estimated Operating Waste Volumes and Activities from the Reference Nuclear Power Plant

A-2 Estimated Maintenance Waste Volumes and Activities from the Reference Nuclear Power Plant.

A-3 Estimated Waste Volumes and Activities for Entombment of the Reference Nuclear Power Plant. 
A-4 Estimated Operating Waste Volumes and Activities from the Reference Fuel

Reprocessing Plant

A-5 Estimated Maintenance Waste Volumes and Activities from the Reference Fue 1

Reprocessing Plant $\quad$ - . . . . . . . . . . A-7

A-6 Estimated Waste Volumes and Activities for

Protective Storage/Dismantlement of the

Reference Fuel Reprocessing Plant . . . . . . A-8

A-7 Estimated Operating Waste Volumes and Activities from the Reference MOX Fuel Fabrication Plant.

A-8 Estimated Maintenance Waste Volumes and Activities from the Reference MOX Fuel Fabrication Plant.

A-9 Estimated Waste Volumes and Activities

from Dismant lement of the Reference MOX Fuel Fabrication Plant. 

WASTES FROM SELECTED ACTIVITIES IN TWO LIGHT-WATER

REACTOR FUEL CYCLES

\section{INTRODUCTION}

The International Nuclear Fuel Cycle Evaluation (INFCE) program was established in 1977 as a cooperative effort among 40 countries and 4 international organizations to review various nuclear power fuel cycle alternatives in search of economical cycles that minimize the risk of nuclear weapons proliferation. The program was organized around several working groups that were established to consider a range of characteristics of fuel cycles, from resource utilization to institutional issues. One working group (WG.7) was charged with the responsibility of comparing a representative selection of nuclear fuel cycles in regard to the management and disposal of radioactive wastes. This report is a result of evaluations in support of WG.7 performed by Pacific Northwest Laboratory under sponsorship of the U.S. Department of Energy.

This report presents projected volumes and radioactivities of wastes from the production of electrical energy using light-water reactors (LWR). The projections are based upon data developed for a recent environmental impact statement $(1-6)$ in which the transuranic wastes (i.e., those wastes containing certain long-lived alpha emitters at concentrations of at least 370 becquerels, or $10 \mathrm{nCi}$, per gram of waste)* from fuel cycle activities were characterized. In addition, since the WG.7 assumed that all fuel cycle wastes except mill tailings are placed in a mined geologic repository, the nontransuranic wastes from several activities are included in the projections reported.

The LWR fuel cycles considered are the LWR, once-through fuel cycle (Strategy 1), in which spent fuel is packaged in metal canisters and then isolated in geologic formations; and the LWR U/Pu recycle fuel cycle (Strategy 2),

*As defined in Reference 7 ; the radionuclides included are $233 \mathrm{U}$ (with its daughter products), plutonium and transplutonium nuclides except $238 \mathrm{pu}$ and $241 \mathrm{Pu}$. 
where in spent fuel is reprocessed for recovery and recycle of uranium and plutonium in LWRs. While not all unit operations of these fuel cycles are considered in this analysis, the fuel element fabrication, reactor, spent fuel packaging and spent fuel reprocessing segments are examined in detail. Wastes from the "head-end" facilities (mining, milling, refining, conversion, and enrichment) are not included because they are considered similar in chemical and radiochemical nature, and can thus be evaluated on the basis of fuel cycle heavy element requirements.

Estimates of waste generation are sensitive to the fundamental assumptions employed, and the assumptions used here are generally consistent with those used by other analysts who supported WG.7. In some cases where no data were available, WG.7 assumptions were modified so that projections could be made. Where our estimates appear to differ significantly from other WG.7 analyses, a comment is provided on the rationale underlying the difference.

\section{SUMMARY}

Tables 1 through 5 summarize the wastes projected for the two LWR fuel cycles. (Waste category numbers in these tables correspond to those shown in Figures 1 and 2.) The reactor operations and decomissioning were found to dominate the rate of waste generation in each cycle. These activities account for at least $85 \%$ of the fuel cycle waste volume (not including head-end wastes) when normalized to per unit electrical energy generated. At 10 years out of reactor, however, spent fuel elements in Strategy 1 represent 98\% of the fuel cycle activity but on $1 y 4 \%$ of the volume. Similarly, the packaged high-level waste, fuel hulls and hardware in Strategy 2 concentrate greater than $95 \%$ of the activity in $2 \%$ of the waste volume.

\section{FUEL CYCLE ASSUMPTIONS}

The fuel cycle characteristics assumed in this analysis are generally those described in Reference 8. Figures 1 and 2 depict the flow and quantities of heavy element materials in the two fuel cycles, as adopted by WG.7.(8) Fuel cycle facility characteristics that were important in the projections are 
TABLE 1. Summary of Packaged Waste Volumes for Reference LWR Fuel Cycles per GWe.yr

\begin{tabular}{|c|c|c|}
\hline Facility & $\begin{array}{l}\text { Pack aged }{ }^{\text {Waste }} \\
\text { Volume, } \mathrm{m}^{3} / \mathrm{GWe} \cdot \mathrm{yr}\end{array}$ & $\begin{array}{l}\text { Fraction of } \\
\text { Total Waste Volume } \\
\end{array}$ \\
\hline \multicolumn{3}{|l|}{ Strategy 1 - (Once-through) } \\
\hline $\mathrm{UO}_{2}$ fuel fabrication & 40 & 0.05 \\
\hline Reactor & 720 & 0.90 \\
\hline Spent fuel packaging & 42 & $\underline{0.05}$ \\
\hline Total & 800 & 1.00 \\
\hline \multicolumn{3}{|l|}{ Strategy $2-(\mathrm{U} / \mathrm{Pu}$ Recycle $)$} \\
\hline $\mathrm{UO}_{2}$ fuel fabrication & 26 & 0.03 \\
\hline $\begin{array}{l}\text { Mixed-oxide fuel } \\
\text { fabrication }\end{array}$ & 21 & 0.02 \\
\hline Reactor & 720 & 0.85 \\
\hline Fuel reprocessing & 85 & $\underline{0.10}$ \\
\hline Total & 850 & 1.00 \\
\hline
\end{tabular}

\section{TABLE 2. Fuel Element Fabrication Wastes for Reference} LWR Fuel Cycles per GWe.yr

INFCE/WG.7

Category

3.1

Description
$\mathrm{UO}_{2}$ fuel waste
Volume
$U$ content

Strategy 1 (once-through)

Strategy 2 (U/Pu recycle)

$\begin{array}{ll}\text { Volume } & \mathrm{m}^{3} \\ U \text { content } & \mathrm{kg} \\ \text { Pu content } & \mathrm{kg}\end{array}$

Mixed-oxide fue 1 waste ${ }^{(b)}$

$\begin{array}{lr}m^{3} & 40 \\ k g & 220\end{array}$

26

150

3.2

220

$\mathrm{kg}$

$\mathrm{kg}$

26

(a) Assumes that on $7 y$ enriched $\mathrm{UF}_{6}$ is converted to $\mathrm{UO}_{2}$ (via the $\mathrm{ADU}$ process). Fluoride waste is disposed of as $\mathrm{CaF}_{2}$ at $70 \%$ of theoretical density. Maintenance and decormissioning wastes are included [decommissioning waste is calculated based upon $1500 \mathrm{MTU} / \mathrm{yr}$ capacity, 30-yr lifetime, and $36.8 \mathrm{MTU} / \mathrm{GWe} \cdot \mathrm{yr}$ (Strategy 1) or $24.8 \mathrm{MTU} / \mathrm{GWe} \cdot \mathrm{yr}$ (Strategy 2) fuel requirements].

(b) Assumes that natural uranium is provided by the refinery as fuel-grade $\mathrm{UO}_{2}$. Maintenance and decomissioning wastes are included (decommissioning waste assumes immediate dismantlement, and is calculated based up on $400 \mathrm{MTHM} / \mathrm{yr}$ capacity, 30-yr 1 ifetime, and $11.8 \mathrm{MTHM} / \mathrm{GWE} \cdot \mathrm{yr}$ mixed-oxide fuel requirement). 


\section{TABLE 3. Reactor Wastes for Reference LWR Fuel Cycles per GWe.yr}

\begin{tabular}{|c|c|c|c|c|}
\hline $\begin{array}{l}\text { NFCE/WG.7 } \\
\text { Category }\end{array}$ & Description & & $\begin{array}{c}\text { Strategy } 1 \\
\text { (once-through) } \\
\end{array}$ & $\begin{array}{c}\text { Strategy } 2 \\
\left(\mathrm{U} / \mathrm{Pu}_{\mathrm{u}} \text { recycle }\right. \\
\end{array}$ \\
\hline \multirow[t]{3}{*}{4.1} & Wastes from operation (a) & & & \\
\hline & Volume & $m^{3}$ & 610 & 610 \\
\hline & Radioactivity & $k C_{i}$ & 5 & 5 \\
\hline \multirow[t]{3}{*}{4.2} & Ma intenance waste $(a, b)$ & & & \\
\hline & Volume & $m^{3}$ & 9 & 9 \\
\hline & Radioactivity & $k i$ & 0.4 & 0.4 \\
\hline \multirow[t]{3}{*}{4.3} & Control rods, etc. (c) & & & \\
\hline & Volume & $m^{3}$ & 5 & 7 \\
\hline & Radioactivity & $k C i$ & 290 & 290 \\
\hline \multirow[t]{3}{*}{4.4} & Decommissioning waste ${ }^{(d)}$ & & & \\
\hline & Volume & $m^{3}$ & 100 & 100 \\
\hline & Radioactivity & $k \in i$ & 2 & 2 \\
\hline
\end{tabular}

(a) Assumes that combustible/compactable wastes are compacted, wet wastes are immobilized in cement, and noncombust ible wastes are packaged directly.

(b) Includes coolant system filter cartridges and ventilation system filters.

(c) Strategy 1: PWR control rods remain inserted with in fuel assemblies, and consequently do not contribute additional pack aged waste volume; BWR control rods are packaged in separate spent fuel canisters.

Strategy 2: All control rods are mechanically dissected and packaged in convenient canisters.

(d) Assumes the reactor is entombed upon shutdown; approximately one-haif the process system (piping) external to the containment building, and all miscellaneous (nonstructural) radioactive wastes are shipped offsite for disposal. Decommissioning waste calculated based upon 1200 MWe installed capacity, 70x load factor, 30-yr lifet ime.

\section{TABLE 4. Unreprocessed Spent Fuel for Reference LWR Fuel Cycles per GWe.yr}

\begin{tabular}{|c|c|c|c|c|}
\hline $\begin{array}{l}\text { INFCE/WG.7 } \\
\text { Category }\end{array}$ & Description & & $\begin{array}{c}\text { Strategy } 1 \\
\text { (once-through) }\end{array}$ & $\begin{array}{c}\text { Strategy } 2 \\
\text { (U/Pu recycle) } \\
\end{array}$ \\
\hline \multirow{7}{*}{5.1} & Treated fuel assemblies(a) & & & \\
\hline & Volume & $m^{3}$ & 35 & -- \\
\hline & Canisters, PWR & & 53 & -- \\
\hline & Can isters, BWR & & 22 & -- \\
\hline & U content & $\mathrm{Mg}$ & 35.7 & - \\
\hline & Pu content & Mg & 0.29 & -- \\
\hline & Radioactivity (10 yr) & $M \boldsymbol{C}$ & 22.7 & - \\
\hline \multirow[t]{3}{*}{5.2} & Spent fuel treatment waste ${ }^{(b)}$ & & & \\
\hline & Volume & $m^{3}$ & 7 & -- \\
\hline & Radioactivity $(10-y z)$ & $k C i$ & 0.15 & - \\
\hline
\end{tabular}

(a) Assumes fuel assemblies are packaged directly in canisters: PWR canister $-0.32 \mathrm{~m} \mathrm{dia} \times 4.9 \mathrm{~m}$ long ( 1 assembly/canister)

BWR canister $-0.41 \mathrm{~m}$ dia $\times 4.9 \mathrm{~m}$ long (3 assemblies/canister).

(b) Assumes only failed fuel assemblies are overpacked (2x frequency). Maintenance and decommissioning wastes are included (decommissioning waste assumes immediate dismant lement and is calculated based upon $2000 \mathrm{MTU} / \mathrm{yr}$ capacity, 30-yr 11 fet ime, and $36.8 \mathrm{MTU} / \mathrm{GWe} \cdot \mathrm{yr}$ fuel requirements). 
TABLE 5. Reprocessing Waste for Reference LWR Fuel Cycles per GWe.yr

INFCE/WG?

Category

6.1

6.3

6.4

6.5

6.6

6.7
Description

Hulls, spacers, insolubles(a)

volume

$U$ content

Pu content

radioactivity

6.2 Vitrified high-level waste $(b)$ volume

$U$ content

Pu content

radioactivity (10 yr)

Noble gases $(c)$

volume

gas flasks

radioactivity

Depleted uranium waste ${ }^{(d)}$

volume (as $\mathrm{UO}_{2}$ )

$U$ content

Medium-level and plant maintenance

waste (e)

volume

$U$ content

$\mathrm{Pu}$ content

radioactivity

Low-level waste ${ }^{(f)}$

volume

radioactivity

Plant decomissioning waste $(g)$

volume

radioactivity
Strategy 1
(once-through

(once-through)

Strategy 2

(U/Pu recycle)

12

18

0.22

$\mathrm{kg} \quad$--

0.94

MC $i \quad--$

4.3

180

2.2

9.9

0.1

$m^{3}-$

3

0.3

$M i$

2.3

$\mathrm{m}^{3} \quad-$

- 11

\section{e}

$m^{3}$

$\mathrm{kg}$

$-$

51

$-$

160

$\mathrm{kg}$

1.4

$k i$

$-$

62

$m^{3} \quad--$

kCi $\quad 0.01$

$\mathrm{m}^{3} \quad-\cdots \quad 6$

kCi $\quad-\infty \quad 0.005$

(a) Assumes uncompacted waste is immobilized in cement. Fuel lost to waste is a ssumed to be $0.05 \mathrm{wt} \%$.

(b) Volume of glass only (packaged volume is 1.25x). Assumes 15 wty waste loading, 0.5 wt\% uranium and plutonium contained in this waste.

(c) Assumes fractional distillation of krypton; stored in $42-2$ cylinders under $34 \mathrm{~atm}$ ( $500 \mathrm{psi}$ ) pressure.

(d) Taken from Reference 5 .

(e) Medium-level waste defined as having a surface dose rate $\geq 0.2 \mathrm{R} / \mathrm{hr}$.

(f) Low-level waste defined as having a surface dose rate $<0.2 \mathrm{R} / \mathrm{hr}$.

(g) Assumes plant is placed in protective storage for $30 \mathrm{gr}$ and then dismant led. 

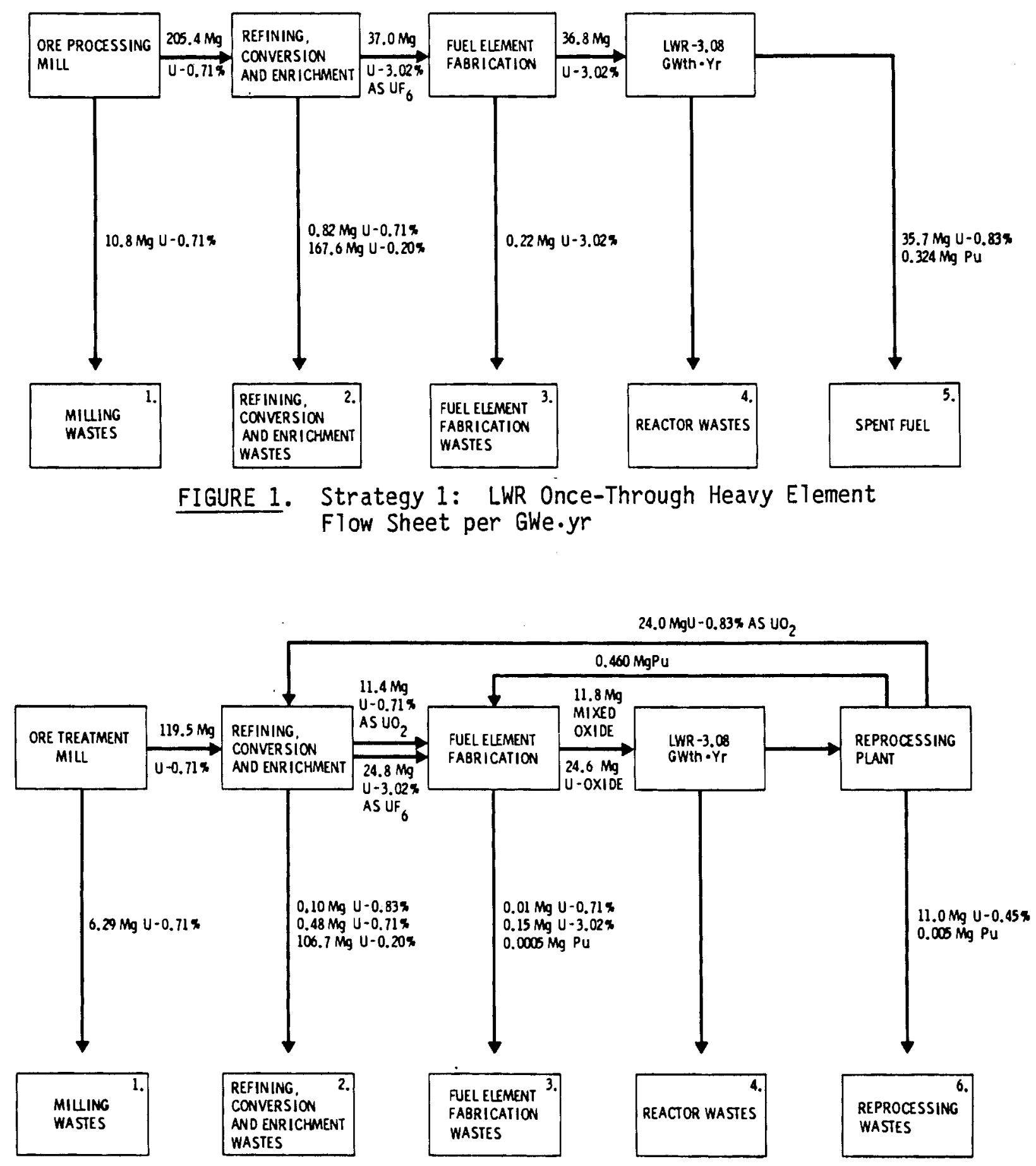

FIGURE 2. Strategy 2: LWR with U-Pu Recycle Heavy Element Flow Sheet per GWe.yr 
presented in Table 6. It is noted that the fuel reprocessing plant (FRP) considered here processes irradiated fuel at twice the rate of the reference facility assumed by WG.7. (8) Nevertheless, we believe that the quantity of most wastes generated at the FRP are proportional to plant throughput over the range of processing rates of interest, so that for the purpose of the INFCE comparative assessment, analysis of the 2000 MTHM/year facility in this paper is acceptable.

In estimates of radioactivity for the various waste streams, a postreactor discharge time of 0.5 year was assumed unless otherwise noted. Significant deviations from this reference cooling time include spent fuel (including waste generated during packaging) and high-level waste (10 years); plutonium fuel fabrication wastes ( 2.5 years); and decomissioning wastes (activity at time of shipment from site).

Except for the reactor, the general decommissioning philosophy for all facilities is dismantlement. It is assumed that all potentially contaminated material is removed from the site; to ensure complete removal, this may include some uncontaminated material. For the FRP, dismantlement is preceded by a 30 -yr protective storage period to allow a reduction in activity levels. (A recent analysis indicates this to be economically more desirable than immediate dismantlement.) ${ }^{(5)}$ For the nuclear power plant, the entombment alternative was selected, wherein the containment building serves as the permanent entombment structure. Only contaminated equipment that will not fit within the internal volume of the structure, and the miscellaneous decontamination and nonstructural wastes are treated and shipped to the repository for disposal.

Final waste volumes depend significantly on the volume reduction and immobilization technologies assumed. In this paper the following treatment assumptions will apply unless otherwise noted:

- Compactable trash/combustible waste: At facilities other than the nuclear power plant, compactable waste is compacted (4:1 volume reduction) and combustible waste is incinerated followed by immobilization of the ash and scrubber solution in cement. Preconcentration of the scrubber solution before solidification in cement is assumed only at the FRP, yielding a 
TABLE 6. Characteristics of the Reference Fuel Cycle Facilities

\section{Strategy 1 Strategy 2}

Uranium Fuel Plant

Nominal processing rate, MTU/year

1500

1500

Plant lifetime, years

30

30

Normalizing factor for decommissioning waste, (a) GWe.yr/plant

1220

1830

Fraction of throughput lost to waste

0.006

0.006

Mixed-0xide Fuel Plant

Nominal processing rate, MTHM/year

$\begin{array}{ll}- & 400 \\ -- & 30 \\ - & 1020 \\ -- & 0.001\end{array}$

Plant lifetime, years

Normalizing factor for decomissioning waste, (a) GWe.yr/plant

Nuclear Power Plant

Ratio of PWRs to BWRS

$2: 1 \quad 2: 1$

Plant installed capacity, MWe

1200

1200

Load factor, \%

70

70

Plant lifetime, years

$30 \quad 30$

Nomalizing factor for decommissioning waste, (b) GWe-yr/plant

25.2

25.2

Average fuel exposure, GWd/MTHM

30

30

Thermal-to-electric conversion efficiency

0.32

0.32

Spent Fuel Packaging Facility

Nominal processing rate, MTHM/year

2000

Plant lifetime, years

30

Normalizjng factor for decomissioning waste, (a) GWe.yr/plant

Fuel Reprocessing Plant

Nominal processing rate, MTHM/year

2000

Plant lifetime, years

$-\quad 30$

Nomalizjng factor for decomissioning waste, (a) GWe.yr plant

$-\quad 1650$
(a) Calculated as: $\quad\left(\begin{array}{c}\text { Processing } \\ \text { rate }\end{array}\right)\left(\begin{array}{c}\text { Plant } \\ \text { lifetime }\end{array}\right)$ ( $\left.\frac{\text { Heavy element weight }}{\text { GWe } \cdot y r}\right)$
(b) Calculated as: $\quad\left(\begin{array}{c}- \text { Plant } \\ \text { Installed Capacity }\end{array}\right)\left(\begin{array}{l}\text { Plant } \\ \text { Lifetime }\end{array}\right)\left(\begin{array}{l}\text { Load } \\ \text { Factor }\end{array}\right)$ 
$5: 1$ volume reduction. In other facilities preconcentration is not assumed (because of the expense of an evaporation system that is resistant to corrosion from chloride, and because of the generally small waste volumes generated). Without preconcentration, there will be no net volume reduction. At the nuclear power plant, incineration was not assumed because few operating LWRs have incinerator systems installed. On the other hand, compaction was assumed since it is frequently used to reduce solid waste volumes, effecting a 4:1 volume reduction for this waste category. In all facilities these wastes are packaged in 200- $\ell$ drums.

- Concentrated liquids, wet waste and particulate solids: Immobilization in cement was universally assumed, which results in a $60 \%$ volume increase over the pretreatment concentrated volume.

- Noncombustible trash, noncompactable scrap, failed equipment: Direct packaging with minimal treatment, leaving the packaged volume the same as the as-generated volume.

\section{FUEL CYCLE PROJECTIONS}

Wastes from activities in LWR fuel cycles, with or without fuel recycle, can be characterized either as operating wastes (generated during operation of the nuclear power plant and other fuel cycle facilities), as maintenance wastes (generated during the periodic maintenance of fuel cycle facilities),* or as decommissioning wastes. Wastes can be further categorized by their physical form or special characteristics: 1) gaseous; 2) compactable trash and combustible wastes, hereafter referred to as "general trash"; 3) concentrated liquids, wet wastes and particulate solids ("wet waste"); 4) failed equipment and noncompactable, noncombustible wastes ("scrap"); 5) HLLW (recycle only); 6) fuel residues (hulls and hardware, recycle on $7 y$ ); and 7) spent fuel

\footnotetext{
*Maintenance wastes were defined by WG.7 to include those created by the scheduled replacement of components in order to prevent failure that is expected but unpredictable. Except as otherwise noted, all ventilation system filters and failed equipment were considered maintenance waste.
} 
(once-through on ly). Wastes are projected according to these categories in subsequent tables; gaseous wastes other than krypton are not included, although secondary wastes arising from gaseous waste treatment are included. Both primary and secondary wastes for other categories are estimated.

Information from a wide variety of sources was evaluated to arrive at these waste projections. Sources include surveys of operating experience at existing fuel cycle facilities; published waste characterizations and projections; other available literature, listed in the partial bibliography; conceptual facility designs; and prevalent operating philosophy.

While waste projections are generally presented to two significant figures, the range of actual volumes and activities to be encountered is large and will vary with facility design philosophy, fuel characteristics, exposure history, fuel and waste age, and specific operating conditions. Two significant figures are provided, not to imply an accuracy of the projections, but to illustrate generic differences among waste streams and treatment alternatives.

The following paragraphs discuss the waste projections by facility and compare the projections with estimates presented in Reference 8 when significant differences are apparent.

\section{URANIUM FUEL FABRICATION PLANT}

Operating wastes in this facility arise from three basic operations: chemical conversion of enriched $\mathrm{UF}_{6}$ to $\mathrm{UO}_{2}$; mechanical processing including pellet production and fuel element fabrication; and recovery of uranium from scrap and off-specification material. It is assumed that chemical conversion is done by the conventional ammonium diuranate (ADU) process, in which the fluoride wastes are disposed of as $\mathrm{CaF}_{2}$ packaged in 200- $\ell$ drums. (9) As no data were available for maintenance waste from this facility, it was arbitrarily assumed to be $10 \%$ of operating waste. Decomissioning of the plant at the end of its economic lifetime would involve decontamination of most process systems to releasable limits and removal of some surface concrete contaminated to levels exceeding those specified by regulatory authorities. The remaining uncontaminated structure is expected to be left in place. 
Table 7 presents the waste projections for this facility. It was assumed that the natural uranium requirements for mixed oxide fuel fabrication are met by means other than conversion of natural $\mathrm{UF}_{6}$ to $\mathrm{UO}_{2}$ at the uranium fue $\mathrm{I}$ plant (e.g., fuel grade natural $\mathrm{UO}_{2}$ may be produced at the refinery and shipped directly to the mixed oxide plant). Thus the requirement for enriched $\mathrm{UO}_{2}$ in Strategy 2 is $67 \%$ of that for Strategy 1 , and the resulting wastes are in the same proportion.

\section{MIXED OXIDE FUEL FABRICATION PLANT}

The principal source of radioactivity in the mixed oxide fuel fabrication plant (MOX-FFP) waste is the plutonium that has been separated from spent fuel at the FRP. The feed material to this facility is dry oxides of natural uranium and plutonium, which are mechanically mixed and pelletized and are then sealed in zirconium alloy tubing to produce mixed oxide assemblies. One year is assumed to elapse between reprocessing and refabrication of fue 1 at the MOX-FFP.

Wastes generated in MOX-FFP operations include bagging plastics, glove box gloves, decontamination solutions, scrap fuel cladding, and plutonium transfer containers. Maintenance wastes include HEPA ventilation filters and failed glove box equipment. Decommissioning of the MOX-FFP involves dismantlement of the facility upon shutdown. The radionuclide inventory in the plant at shutdown is based upon an accumulation of $1 \mathrm{~kg} \mathrm{Pu}$ (with $22 \mathrm{~kg} \mathrm{U}$ ) per year over the 30-yr lifetime of the plant. This accumulation represents $\sim 0.005$ wt\% of the plant throughput. Table 8 presents the projected waste arisings for the MOX-FFP. Tables A-7 through A-9 of the Appendix provide additional detail regarding these wastes.

\section{NUCLEAR POWER PLANT}

The wastes from the reference nuclear power plant represent a composite of wastes that would result from operation of LWRs at a ratio of 2 PWRs:1 BWR. The wastes generated in routine operations are assumed to be identical in both fuel cycle strategies. They include 1) combustible trash from servicing 
TABLE 7. Estimated Waste Volumes and Activities from the Reference Uranium Fuel Fabrication Plant (a)

Strategy 1: LWR Once Through

\begin{tabular}{|c|c|c|}
\hline $\begin{array}{l}\text { Volume, } \\
\text { As Generated }\end{array}$ & $\begin{array}{l}\text { /GWe -yr } \\
\text { As Shipped }\end{array}$ & $\begin{array}{l}\text { Activity, (c) } \\
\text { Ci/GWe.yr }\end{array}$ \\
\hline 64 & 12 & $N S^{(d)}$ \\
\hline 21 & 21 & $\begin{array}{l}9.9 \mathrm{E}-2 \\
\text { (2.2E5 g urunium) }\end{array}$ \\
\hline 7 & 7 & NS \\
\hline 95 & 40 & $\begin{array}{c}\text { 0.9E-2 Ci } \\
\text { (2.2E5 g uranium) }\end{array}$ \\
\hline
\end{tabular}

Strategy 2: LWR U/PU Recycle

\begin{tabular}{|c|c|c|}
\hline \multicolumn{2}{|c|}{ Volume, $m^{3} /$ GWe -yr } & \multirow{2}{*}{$\begin{array}{l}\text { Activity, } \\
\text { Ci/GWe-yr }\end{array}$} \\
\hline As Generated & As Shipped (b) & \\
\hline 43 & 8 & NS \\
\hline 14 & 14 & $\begin{array}{l}7.1 \mathrm{E}-2 \\
\text { (1.5E5 g uranium) }\end{array}$ \\
\hline-4 & 4 & NS \\
\hline 63 & 26 & $\begin{array}{c}7.1 \mathrm{E}-2 \mathrm{Ci} \\
\text { (1.5E5 g uranium) }\end{array}$ \\
\hline
\end{tabular}

(a) $1500 \mathrm{MTU} / \mathrm{yr}$ plant capacity, $30-y r$ lifetime; uranium requirements are $36.6 \mathrm{MTU} / \mathrm{GWe}$ yr in Strategy 1 , 24.6 MTU/GWe.yr in Strategy 2; projections include operating, maintenance and decommissioning wastes.

(b) As-shipped volume assumes combustibles are incinerated, compactables are compacted, wet waste (except Caf2) is immobilized in feinent, and scrap is packaged directly.

(c) Assumes $3.02 \% 235 \mathrm{U}$ enrichment, $0.6 \mathrm{wt} \%$ of throughput inst to waste.

(d) Not significant. 
TABLE 8. Estimated Waste Volumes and Activities from the Reference Mixed-Oxide Fue 1 Fabrication Plant (a)

\begin{tabular}{|c|c|c|c|c|c|}
\hline \multirow[b]{2}{*}{ Waste Stream } & \multicolumn{2}{|c|}{ Volume, $m^{3} / G$ He. $y r$} & \multicolumn{3}{|c|}{ Activity, Ci/GWe.yr (c) } \\
\hline & As Generated & As Shipped (b) & $U$ & $\mathrm{Pu}$ & $\begin{array}{c}\text { Other } \\
\text { Actinides }\end{array}$ \\
\hline \multicolumn{6}{|l|}{ Operating Waste } \\
\hline General trash & 5.9 & 5.9 & $\begin{array}{l}5.6 \mathrm{E}-2 \\
(3.4 \mathrm{E} 3 \mathrm{~g})\end{array}$ & $\begin{array}{l}2.1 \mathrm{E3} \\
(1.5 \mathrm{E} 2 \mathrm{~g})\end{array}$ & $3.5 E 1$ \\
\hline Wet waste & 4.3 & 7.0 & $\begin{array}{l}2.0 \mathrm{E}-2 \\
(1.2 \mathrm{E} 3 \mathrm{~g})\end{array}$ & $\begin{array}{l}7.6 \mathrm{E} 2 \\
(5.5 \mathrm{E} 1 \mathrm{~g})\end{array}$ & 2.3EO \\
\hline Scrap & 2.4 & 2.4 & $\begin{array}{l}1.8 \mathrm{E}-3 \\
(1.1 \mathrm{E} 2 \mathrm{~g}) \\
\end{array}$ & $\begin{array}{l}6.9 E 1 \\
(5.0 E D g) \\
\end{array}$ & $1.1 E O$ \\
\hline Total operating waste & 13 & 15 & $\begin{array}{l}7.8 E-2 \\
(4.7 E 3 g)\end{array}$ & $\begin{array}{l}2.9 \mathrm{E} 3 \\
(2.1 \mathrm{E} 2 \mathrm{~g})\end{array}$ & $3.8 E 1$ \\
\hline \multicolumn{6}{|l|}{ Maintenance Waste $^{(d)}$} \\
\hline General trash & 1.2 & 1.2 & $\begin{array}{l}1.3 \mathrm{E}-1 \\
(7.8 \mathrm{E} 3 \mathrm{~g})\end{array}$ & $\begin{array}{l}4.9 E 3 \\
(3.3 E 2 g)\end{array}$ & $8.0 E 1$ \\
\hline Scrap & 2.4 & 2.4 & $\begin{array}{l}1.8 \mathrm{E}-3 \\
(1.1 \mathrm{E} 2 \mathrm{~g}) \\
\end{array}$ & $\begin{array}{l}6.9 \mathrm{El} \\
(5.0 \mathrm{EOg}) \\
\end{array}$ & $1.1 \mathrm{EO}$ \\
\hline $\begin{array}{l}\text { Total maintenance } \\
\text { waste }\end{array}$ & 3.6 & 3.6 & $\begin{array}{l}1.3 \mathrm{E}-1 \mathrm{~g} \\
(7.9 \mathrm{E} 3 \mathrm{~g})\end{array}$ & $\begin{array}{l}5.0 E 3 \\
(3.4 E 2 g)\end{array}$ & $8.1 \mathrm{El}$ \\
\hline \multicolumn{6}{|l|}{ Decommissioning Waste $^{(e)}$} \\
\hline General trash & 0.1 & 0.1 & $\begin{array}{l}2.9 \mathrm{E}-3 \\
(2.5 \mathrm{E} 2 \mathrm{~g})\end{array}$ & $\begin{array}{l}9.5 E 1 \\
(1.0 E I g)\end{array}$ & 2.0EO \\
\hline Wet waste & 0.3 & 0.2 & $\begin{array}{l}1.1 \mathrm{E}-3 \\
(9.6 \mathrm{Elg})\end{array}$ & $\begin{array}{l}3.7 \mathrm{EI} \\
(4.0 \mathrm{EOg})\end{array}$ & $7.8 E-1$ \\
\hline Scrap & 2.4 & 2.4 & $\begin{array}{c}2.9 E-3 \\
(2.6 E 2 g)\end{array}$ & $\begin{array}{c}9.9 \mathrm{El} \\
(1.1 \mathrm{Elg}) \\
\end{array}$ & $2.1 \mathrm{EO}$ \\
\hline $\begin{array}{l}\text { Total decomissioning } \\
\text { waste }\end{array}$ & 2.8 & 2.7 & $\begin{array}{r}6.9 E-3 \\
(6.1 \mathrm{E} 2 \mathrm{~g}) \\
\end{array}$ & $\begin{array}{l}2.3 E 2 \\
2.5 E 1 g) \\
\end{array}$ & 4.9EO \\
\hline $\begin{array}{l}\text { Total mixed oxide fuel } \\
\text { plant waste }\end{array}$ & 19 & 21 & $\begin{array}{c}2.1 E-1 \\
(1.3 E 4 g)\end{array}$ & $\begin{array}{l}8.1 \mathrm{E3} \\
(5.8 \mathrm{E} 2 \mathrm{~g})\end{array}$ & $1.2 \mathrm{E2}$ \\
\hline
\end{tabular}

(a) The MOX fuel fabrication plant is assumed to be operated and maintained by contact means, with a nominal throughput of $400 \mathrm{MTHM} / \mathrm{yr}, 11.8 \mathrm{MTHM} / \mathrm{GWe}-\mathrm{yr}$, and $30-\mathrm{yr}$ lifetime.

(b) As-shipped volumes assume compactable waste is compacted, combustible waste is incinerated, wet wastes are immobilized in cement, and scrap waste is packaged directly.

(c) Activities are at $2.5 \mathrm{yr}$ after reactor discharge.

(d) Includes failed equipment and ventilation filters.

(e) Decomissioning alternative is immediate dismantlement upon shutdown. Assumes an accumulation of $1 \mathrm{~kg} \mathrm{Pu} / \mathrm{yr}$ and $22 \mathrm{~kg} \mathrm{U} / \mathrm{yr}$ over the $30-\mathrm{yr}$ lifet ime of the facility. 
coolant system plumbing; 2) water cleanup wastes such as ion exchange resins and evaporator bottoms; 3) filter precoat sludges from blowback of coolant filters; and 4) noncompactable trash such as coolant reheaters, steam generators, and turbine parts. Sources of radioactivity in the wastes include neutron activation of structural metals and their corrosion products; irradiation of tramp uranium on the external surfaces of fuel elements; neutron activation of coolant components including coolant additives; and fission products from irradiated fuel, in the event of fuel rod cladding failure.

The maintenance wastes from the reactor include spent coolant system cartridge filters, ventilation system filters, and activated core parts such as control elements and flow channels. Because of the extremely high concentration of activation products in the core parts, these materials were estimated separately. Note that although it is assumed that PWR control rods in Strategy 1 are packaged with spent PWR fuel (thereby contributing no additional waste volume), the net fuel cycle volume for this waste category is still nearly as large as for Strategy 2 (in which all control rods are packaged separately). This is because in a fuel cycle having nuclear power plants in the ratio of two PWRs to one BWR, the BWR contributes about threefourths of the core-parts waste volume. Hence a relatively significant economy in PWR core-part volume still results in a minor reduction for the Strategy 1 fuel cycle.

The nuclear power plant may be decommissioned in one of two ways: immediate entombment (assumed in this report) or dismantlement. Entombment of the nuclear power plant involves placement of as much contaminated equipment and structural components as possible (60\% in the case of a PWR) within the portion of the containment building below ground level, which is then covered by a thick, reinforced concrete slab. All penetrations to the structure are permanently sealed, and the external surfaces may have an impermeable sealant applied. All contaminated materials not placed within the entombment structure are appropriately treated, packaged and shipped for disposal.

Dismantlement, which has been described in another study, (10) involves complete removal of contaminated materials from the site to the extent required 
to terminate the facility license. This may include removal of some uncontaminated structural materials to ensure compliance with regulatory requirements. The actual dismantling activities may be preceded by an interim protective storage period (e.g., 50 years) to allow for decay of ${ }^{60}$ co.

Table 9 shows the distribution of nuclear power plant wastes that were estimated. Refer to Appendix Tables A-1 through A-3 for details. Comparison of these estimates with the INFCE/WG.7 Table of Waste Arisings ${ }^{(8)}$ requires two comments. First, operating wastes in Table 9 are large in volume compared to other fuel cycles evaluated by WG.7.* The estimate is based upon actual operating data obtained from existing LWRs in the United States, where shallowland burial is routinely practiced. If the more expensive geologic disposal constraint assumed in this study were actualiy imposed upon nuclear power plant operators, a greater incentive for waste volume reduction would exist, thereby lowering the projected waste volume. The second comment is that the projected decommissioning volume presented here assumes that only the portion of the reactor containment building below grade is available for use as the entombment structure, requiring that some $75 \mathrm{~m}^{3} /$ GWe.yr of contaminated piping and equipment be sent offsite for disposal. If all such wastes remain onsite in an enlarged entombment structure, then a smaller repository waste volume will result.

\section{SPENT FUEL PACKAGING FACILITY}

The spent fuel packaging facility (SFPF) receives fuel that has been in inter im storage at the reactor or at an independent storage basin. The reference fuel age for repository emplacement is taken to be 10 years, thus it is assumed that the SFPF receives fuel at 9 years out of reactor. Wastes from about 8.5 years of interim spent fuel storage are not included in this analysis.

\footnotetext{
*Actualiy, operating and maintenance wastes should be summed before comparison of waste arisings among different fuel cycles. This is because the distinction between operating wastes and maintenance wastes for many facilities and activities is difficult to discern. Taken together, they represent a fairly consistent category of wastes amenable to intercycle comparison.
} 
TABLE 9. Estimated Waste Volumes and Activities from the Reference Nuclear Power Plant (a)

Volume, $m^{3} /$ GHe.yr

Waste Stream

$\frac{\text { Volume, } m^{3} / \text { GWe-yr }}{\text { As Generated As Shipped (b) }}$

Activity, Ci/GWe.yr(c) Activation Fission Products Products

Operating Waste

$\begin{array}{lrrll}\text { General trash } & 190 & 48 & 5.8 E 1 & 2.8 E 0 \\ \text { Wet waste } & 330 & 520 & 1.0 E 3 & 4.0 E 3 \\ \text { Scrap } & \frac{38}{558} & \frac{38}{606} & \frac{1.7 E-1}{1.1 E 3} & \frac{8.0 E-1}{4.0 E 3} \\ \quad \text { Total operating waste } & 5303 & \end{array}$

Maintenance Waste ${ }^{(d)}$

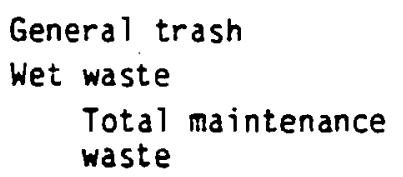

$\begin{array}{lrrr}5 & 1 & 4.2 E O & 3.2 E O \\ 5 & 8 & 3.5 E 2 & 2.0 E O \\ 10 & 9 & 3.5 E 2 & 5.2 E O\end{array}$

Core Parts

Control rods(e)

Total core parts

$\frac{6}{6} \quad \frac{5 \text { or } 7}{5 \text { or } 7} \quad \frac{1.9 E 5}{1.9 E 5} \quad \frac{1.2 E 0}{1.2 E 0}$

Vecomissioning Waste $(f)$

General trash and wet waste

Scrap

Total decormissioning wastes

Total nuclear power plant wastes

$\begin{array}{llll}- & 18 & 1.9 E 3 & \text { NS } \\ - & 83 & \underline{4.0 E 1} & \text { NS } \\ - & 101 & 1.9 E 3 & \text { NS } \\ 574 & 723 & 1.9 E 5 & 4.0 E 3\end{array}$

(a) Light water reactors, at equilibrium operation, 2/3 PWR $-1 / 3$ BWR, 1200 MWe generating capacity each, 70\% load factor, 30 GWth.d/MTHM average fuel exposure, 32\% thermal-to-e lectric conversion efficiency, $36.4 \mathrm{MTHM} / \mathrm{GWe} \cdot \mathrm{yr}$, approximately one-third of fuel is assumed to be mixed-oxide.

(b) As-shipped volume assumes general trash is compacted, wet wastes are immobilized in cement, and scrap is packaged directly.

(c) Activities are at 0.5 year.

(d) Includes coolant system filter cartridges and ventilation filters.

(e) Strategy 1: PWR control rods remain inserted within fuel assemblies and are packaged in spent fuel canisters; BWR control rods are packaged in separate spent fuel canisters. Resulting volume is $5 \mathrm{~m}^{3} /$ GWe.yr.

Strategy 2: All control rods are mechanically dissected and packaged in convenient can isters. Resulting volume is $7 \mathrm{~m}^{3} / \mathrm{GWe} \cdot \mathrm{yr}$.

(f) Decomissioning alternative for the nuclear power plant is entombment. 
The SFPF receives fuel assemblies into its heavily shielded air environment through a water-filled canal from the cask unloading station. The assemblies are dried and inspected for damage before packaging. Unfailed fuel assemblies are sealed in single helium-filled stainless steel canisters ( 3 BWR assemblies per canister, or 1 PWR assembly per canister). Failed assemblies (expected to occur at $2 \%$ frequency) are placed in similar canisters, followed by overpacking to provide double encapsulation. After inspection for helium leakage the packaged fuel is sent to the repository for disposal.

Secondary wastes generated at the SFPF are primarily combustible trash and decontamination solutions from the receiving and loadout stations, and water treatment system wastes. Small quantities of tools and failed equipment are also produced. The facility is assumed to be dismantled at the end of its useful life, with small quantities of contaminated material being sent to the repository. The SFPF wastes are characterized in Table 10.

\section{FUEL REPROCESSING PLANT}

The FRP consists of five integrated facilities: the spent fuel storage basin, the fuel dissolution and solvent extraction facility (the main plant), the plutonium conversion facility, the $\mathrm{UF}_{6}$ facility, and the waste management facility. Each facility has operations that are unique in the fuel cycle; therefore, the waste streams from the FRP are the most diverse of any facility in the post-fission LWR-MOX fuel cycle.

of the several waste streams generated in the FRP, the two with the highest specific radioactivity are HLLW and fuel residues. HLLW is the concentrated raffinate from the first-cycle extractor combined with dissolver sludge. It contains $99 \%$ of the fission products and actinides other than uranium and plutonium ( $0.5 \%$ loss assumed) that are originally in the spent fuel. In addition, significant quantities of reprocessing chemicals are present in varying concentrations, depending upon the particular flowsheet selected. This paper assumes the reference HLLW composition given in Reference 3; the waste is composed of $52 \mathrm{~kg}$ total oxides per MTHM (including 
TABLE 10. Estimated Waste Volumes and Activities from the Reference Spent Fuel Packaging Facility(a)

Waste Strean

$\frac{\text { Volume, } \mathrm{m}^{3} / \text { GWe.yr }}{\text { As Generated As Shipped (b) }}$

$\frac{\text { Activity, } C i / G W e \cdot y r(c)}{\text { Activation Fission }}$

Products Products

\section{Operating Waste}

General trash

Het waste

17

0.2

4.3

0.3

4.7E-1

S.0E1

Scrap

Total operating wastes

$\frac{0.01}{17.2}$

0.01

4.7E-1

$5.0 E 1$

$2.5 E-3 \quad 2.6 E-1$

Maintenance Haste ${ }^{(d)}$

General trash

Scrap

Total maintenance

wastes

0.5

4.6

$9.4 \mathrm{E}-1$

1. OE2

Decommissioning Waste ${ }^{(e)}$

General trash
Wet waste
Scrap
$\quad$ Total decommissioning
wastes
Total packaging facility
wastes (excluding fuel)

\subsection{3}

0.01

0.1

4.7E-3

$5.0 E-1$

$\underline{1.8}$

$\underline{1.8}$

4.7E-1

$5.0 E 1$

2.3

1.9

4. 7E-1

5.1E1

\section{$\underline{0.83}$}

0.01

0.02

$\underline{0.83}$

0.87

0.86

-

20.4

7.4

1. $4 E 0$

4.7E-3

$\begin{array}{ll}\text { NS } & 4.7 E-3 \\ \text { NS } & 7.1 E-3\end{array}$

NS $\quad$ 7.1E-3

Volume, $m^{3} / G$ We.yr

Haste Stream

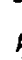

Spent Fuel

\begin{tabular}{|c|c|c|c|}
\hline \multicolumn{4}{|c|}{ Activity, Ci/GWe-yr(c) } \\
\hline $\begin{array}{l}\text { AP and } \\
F P(g)\end{array}$ & 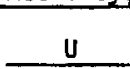 & $P_{u}$ & $\begin{array}{c}\text { Other } \\
\text { Actinides }\end{array}$ \\
\hline $\begin{array}{l}A P: 6.8 E 4 \\
F P: 9.9 E 6\end{array}$ & $\begin{array}{l}8.6 E 1 \\
(3.6 E 7 g)\end{array}$ & $\begin{array}{c}2.6 \mathrm{EG} \\
(2.9 \mathrm{Eg})\end{array}$ & $1.2 \mathrm{E} 5$ \\
\hline
\end{tabular}

(a) Spent fuel is received at 9 yr out of reactor. The SFPF has a $2000 \mathrm{MTHM} / \mathrm{yr}$ capacity and a $30-y \mathrm{r}$ lifetime, $36.8 \mathrm{MTHM} / \mathrm{GWe}-\mathrm{yr}$.

(b) As-shipped volume assumes general trash is compacted, wet wastes are imobilized in cement, and scrap is pack aged direct ly.

(c) Activity is at $10 \mathrm{yr}$ out of reactor.

(d) Includes failed equipment and vent ilation filters.

(e) Decomissioning alternative is dismant lement inmediately upon shutdown.

(f) Assumes cylindrical can isters:

PWR $-0.32 \mathrm{~m}$ dia $\times 4.9 \mathrm{~m}$ (1 assembly each)

BUR - $0.41 \mathrm{~m}$ dia $\times 4.9 \mathrm{~m}$ ( 3 assemblies each).

(g) AP: activation products; FP: fission products. 
$32 \mathrm{~kg}$ of fission product oxides). This waste is combined with glass-forming additives to produce a borosilicate glass cast in stainless steel canisters. To meet the WG.7 criterion of 9 wt\% fission product oxides in glass, a waste loading of $15 \mathrm{wt} \%$ HLW oxides is specified. Table 11 indicates the resulting HLW glass volume; the total packaged volume is about $5.4 \mathrm{~m}^{3} /$ GWe.yr.

The fuel residues include hulls and assembly hardware resulting from fuel disassembly, shearing, and dissolution operations. The radioactivity in the assembly hardware is from neutron activation of the constituent metals. The activity of the hulls includes activation products plus actinides and fission products from undissolved residual fuel (0.05\% loss assumed). The fuel residues are assumed to be mixed with cement and packaged in suitable canisters for disposal. The resulting waste characteristics, shown in Table 11, are based upon the assumption that waste loading in cement is equal to that achievable by pouring uncompacted residues into the canister with sand added as an inert filler. (3) Comparison of these characteristics with Reference 8 reveals that a more conservative assumption could have been used; that is, cement immobilization may increase the bulk volume of fuel residues by $70 \%$. Reference 8 also assumes that a larger fraction of the spent fuel remains und issolved with the fuel residues.

If irradiated $\mathrm{UO}_{2}$ and $\mathrm{MOX}$ fuel assemblies are processed through the FRP separately, then it is conceptually possible to isolate uranium recovered from MOX fuel and discard it as waste. This analysis did not assume separate processing of the two kinds of fuel, and therefore does not present an independent estimate of the waste generated. However, some $11 \mathrm{MTU} / \mathrm{GWe} \cdot \mathrm{yr}(8)$ of depleted uranium will be recovered. If this is disposed of as $\mathrm{UO}_{2}$, and assuming $50 \%$ of theoretical density, about $2.3 \mathrm{~m}^{3} /$ GWe.yr of packaged waste would result.

Other FRP wastes arising from routine operations include solvent cleanup wash solutions, second- and subsequent-cycle solvent extraction raffinates, ion-exchange resins and bead resins from storage basin water cleanup. Main plant and storage basin combustible trash and main plant noncombustible scrap are also significant in volume. Maintenance wastes comprise a smaller volume but contain considerable activity, especially in the case of main plant and 
TABLE 11. Estimated Waste(a) Volumes and Activities from the Reference Fuel Reprocessing Plant(b)

Waste Stream

\section{Operating Waste}

Noble gases(e)

General trash

Wet waste

Serap

Total non-high level operating wastes

High-level liquid waste

Fuel residues

Total operating

Maintenance Waste (i)

General trash

Scrap

Total maintenance

waste

Decomissioning Waste $(j)$

General $\operatorname{trash}(k)$

Wet waste

Scrap

Total decomissioning waste

Total fuel reprocessing plant wastes
Volume, $m^{3} /$ GWe.yr

As Generated As Shipped (c)

Activity, Ci/GWe.yr ${ }^{(d)}$

\begin{tabular}{|c|c|c|c|}
\hline $\begin{array}{l}\text { Fission } \\
\text { Products }\end{array}$ & $U$ & Pu & $\begin{array}{c}\text { Other } \\
\text { Activities }\end{array}$ \\
\hline
\end{tabular}

\begin{tabular}{|c|c|c|c|c|c|}
\hline- & 0.1 & $2.7 E 5$ & NS & NS & NS \\
\hline 83 & 17 & $5.8 \mathrm{E} 2$ & $\begin{array}{c}1.0 E-1 \\
(1.8 E 4 g)\end{array}$ & $\begin{array}{c}4.1 E 3 \\
(2.7 E 2 g)\end{array}$ & $4.2 E 0$ \\
\hline 9 & 15 & $3.4 E 4$ & $\begin{array}{c}7.6 \mathrm{E}-1 \\
(1.4 \mathrm{E} 5 \mathrm{~g})\end{array}$ & $\begin{array}{c}6.8 E 3 \\
(4.4 E 2 g)\end{array}$ & $2.0 E 1$ \\
\hline 17 & 17 & $1.2 \mathrm{E2}$ & $\begin{array}{c}2.0 \mathrm{E}-2 \\
(3.6 \mathrm{E} 3 \mathrm{~g})\end{array}$ & $\begin{array}{c}6.5 E 2 \\
(4.4 E 1 g)\end{array}$ & $2.1 E 0$ \\
\hline 109 & 49 & $3.0 E 5$ & $\begin{array}{c}8.8 \mathrm{E}-1 \\
(1.6 \mathrm{E} 5 \mathrm{~g})\end{array}$ & $\begin{array}{l}1.2 \mathrm{E} 4 \\
(7.5 \mathrm{E} 2 \mathrm{~g})\end{array}$ & $2.6 E 1$ \\
\hline 22 & $4.3(f)$ & $9.7 E 6$ & $\begin{array}{c}7.3 \mathrm{E}-1 \\
(1.8 \mathrm{E} 5 \mathrm{~g})\end{array}$ & $\begin{array}{c}2.4 E 4 \\
(2.2 E 3 g)\end{array}$ & $1.8 E 5$ \\
\hline 12 & $12(9)$ & $\begin{array}{l}\text { AP: }(h)_{8.7 E 5} \\
\text { FP: } \quad 6.2 E 4 \\
\end{array}$ & $\begin{array}{c}1.0 \mathrm{E}-1 \\
(1.8 \mathrm{E} 4 \mathrm{~g})\end{array}$ & $\begin{array}{c}3.5 E 3 \\
(2.2 E 2 g) \\
\end{array}$ & $9.8 E 2$ \\
\hline 143 & 65 & $\begin{array}{ll}\text { AP: } & 8.7 E 5 \\
\text { FP: } & 1.1 E 7\end{array}$ & $\begin{array}{l}1.7 \mathrm{EO} \\
(3.6 \mathrm{E5g})\end{array}$ & $\begin{array}{c}4.0 E 4 \\
(3.2 E 3 g)\end{array}$ & $1.8 E 5$ \\
\hline
\end{tabular}

\begin{tabular}{|c|c|c|c|c|c|}
\hline 6 & 2 & $1.2 E 3$ & $\begin{array}{c}4.0 E-3 \\
(6.1 \mathrm{E} 2 \mathrm{~g})\end{array}$ & $\begin{array}{c}1.3 E 4 \\
(8.8 E 2 g)\end{array}$ & $2.0 E 1$ \\
\hline 9 & 9 & $1.2 E 2$ & $\begin{array}{c}2.2 \mathrm{E}-3 \\
(4.0 \mathrm{E} 2 \mathrm{~g})\end{array}$ & $\begin{array}{c}7.0 \mathrm{E} 2 \\
(4.4 \mathrm{Elg})\end{array}$ & 2.050 \\
\hline 15 & 11 & $1.3 E 3$ & $\begin{array}{l}6.2 \mathrm{E}-3 \\
(1.0 \mathrm{E} 3 \mathrm{~g})\end{array}$ & $\begin{array}{c}1.4 \mathrm{E4} \\
(9.2 \mathrm{E} 2 \mathrm{~g})\end{array}$ & $\overline{2.2 E 1}$ \\
\hline
\end{tabular}

\begin{tabular}{|c|c|c|c|c|c|c|}
\hline 0.6 & 0.7 & & $7.4 E-1$ & $\begin{array}{c}2.8 E-5 \\
(4.8 E l g)\end{array}$ & $\begin{array}{c}4.2 E-1 \\
(1.9 E-1 g)\end{array}$ & $1.1 E-1$ \\
\hline 0.3 & 0.4 & & $9.0 E-1$ & $\begin{array}{c}7.5 E-6 \\
(1.3 E \lg )\end{array}$ & $\begin{array}{c}1.1 E-1 \\
(4.9 E-2 g)\end{array}$ & $3.0 E-2$ \\
\hline 5.0 & 5.0 & & $2.4 E 0$ & $\begin{array}{c}3.5 E-5 \\
(5.8 E 1 \mathrm{~g})\end{array}$ & $\begin{array}{c}5.2 E-1 \\
(2.3 E-1 g)\end{array}$ & $1.4 E-1$ \\
\hline 5.9 & 6.1 & & $4.0 E 0$ & $\begin{array}{c}7.1 E-5 \\
(1.2 E 2 g)\end{array}$ & $\begin{array}{l}1.1 \mathrm{EO} \\
(4.7 \mathrm{E}-1 \mathrm{~g})\end{array}$ & $2.8 E-1$ \\
\hline 60 & 82 & $\begin{array}{l}\text { AP: } \\
\text { FP: }\end{array}$ & $\begin{array}{l}8.7 E 5 \\
1.1 E 7\end{array}$ & $\begin{array}{l}1.7 E 0 \\
(3.6 E 5 \mathrm{~g})\end{array}$ & $\begin{array}{c}5.4 E 4 \\
(4.1 E 3 g)\end{array}$ & $1.8 \mathrm{E} 5$ \\
\hline
\end{tabular}

(a) Includes transuranic and nontransuranic wastes.

(b) The fuel reprocessing plant is assumed to be of conventional design based on the PUREX flowsheet, with a nominal throughput of $2000 \mathrm{MTHM} / \mathrm{yr}, 36.4 \mathrm{MTHM} / \mathrm{GHe} \cdot \mathrm{yr}, 30-\mathrm{yr}$ lifet ime.

(c) As-shipped volume assumes combustibles are incinerated and immobilized in cement, compactables are compacted, wet wastes are imobilized in cement, and scrap wastes are packaged directly.

(d) Activity at $0.5 \mathrm{yr}$ after reactor discharge, except for certain PuO $0_{2}$ conversion wastes (1.5 yr), high-level liquid waste $(10 \mathrm{yr}$ ), and decomissioning wastes (shutdown $+30 \mathrm{yr}$ ).

(e) Assumes fractional distillation, yielding a mixture, $80 \%$ of which is krypton; gas cylinder storage at 34 atm (500 psi).

(f) Volume of waste glass on ly; packaged volume is greater by $1.25 x, i . e ., 5.4 \mathrm{~m}^{3} / \mathrm{GWe} \cdot \mathrm{yr}$.

(g) Fuel residues as-shipped volume assumes cementation of uncompacted hulls and hardware.

(h) AP: activation products; FP: fission products.

(i) Includes HEPA filters and failed equipment from the main reprocessing plant, the $P_{2} 0_{2}$ conversion facility, and portions of the UF 6 conversion facility.

(j) Decommissioning alternative is $30-y r$ protective storage (to reduce exposure levels) followed by facility dismant lement.

(k) HEPA filters are packaged without compaction, thereby increasing the final shipping volume. 
$\mathrm{PuO}_{2}$ conversion facility ventilation filters. Wastes in these categories are treated as described above and packaged in $200-\ell$ drums.

Decomissioning of the FRP involves placing the facility into a 30-yr protective storage mode before dismantlement. Operations include chemical and mechanical decontamination and fixation of residual decontamination, deactivation of equipment, isolation of contaminated areas, and final interim storage preparations such as sealing doors and installing security systems and radiation detection equipment. At the end of the protective storage period, normal dismantling activities are undertaken. Waste treatment systems installed at the FRP are used to treat decommissioning wastes to the extent possible. 0ther wastes are packaged for shipment to another treatment facility and subsequently are sent to the geologic repository.

Table 11 sumarizes FRP wastes according to operating, maintenance, and decommissioning categories, for which additional detail is provided in Appendix Tables A-4 through A-6. The Working Group 7 report structure distinguishes between medium-level and low-level operating wastes as we11, using a package surface dose rate of $0.2 \mathrm{R} / \mathrm{hr}$ as the distinguishing characteristic. Using data provided in Reference 6, Appendix 10, the operating wastes shown in Table 11 of this report have been restructured to indicate the distribution between dose rate classes, and are presented in Table 12 . The only significant FRP wastes likely to occur in the lower class are the incinerator scrubber solution, most $U F_{6}$ plant wastes, and $\mathrm{PuO}_{2}$ conversion plant glove box wastes.

TABLE 12. Sumary of Operating Wastes from the Reference Fue 1 Reprocessing Plant by Package Dose Rate(a)

\begin{tabular}{|c|c|c|c|c|}
\hline \multirow[b]{2}{*}{ Waste Category } & \multicolumn{2}{|c|}{ No Shielding Required } & \multicolumn{2}{|c|}{ Shielding Required $(c)$} \\
\hline & Volume, $\mathrm{m}^{3} / \mathrm{GWe} \cdot \mathrm{yr}$ & Activity, Ci/GWe.yr & Volume, $\mathrm{m}^{3} /$ GWe.yr & Activity, Ci/GWe.yr \\
\hline General trash & 7 & $1.1 E 1$ & 10 & $4.7 E 3$ \\
\hline Wet waste & - & - & 15 & $4.1 E 4$ \\
\hline Scrap & $\underline{2}$ & $\underline{1.9 E-1}$ & $\underline{15}$ & $7.7 E 2$ \\
\hline Total & 9 & $1.1 E 1$ & 40 & $4.7 E 4$ \\
\hline
\end{tabular}

(a) Distribution of wastes between the two dose rate categories was estimated from

(b) Surface dose rate $<0.2 \mathrm{R} / \mathrm{hr}$.

(c) Surface dose rate $\geq 0.2 \mathrm{R} / \mathrm{hr}$. 


\section{REFERENCES}

1. United States Department of Energy, Draft Environmental Impact Statement: Management of Commercially Generated Radioactive Waste, DOE/EIS-0046-0, VoT. 1 and 2, April 1979.

2. United States Department of Energy, Technology for Commercial Radioactive Waste Management, Vol. 1: "Introduction, Bases, and Background Information," DOE/ET-0028, May 1979.

3. United States Department of Energy, Technology for Commercial Radioactive Waste Management, Vo 1. 2: "Waste Treatment Technology," DOE/ET-0028, May 1979.

4. United States Department of Energy, Technology for Commercial Radioactive Waste Management, Vo 1. 3: "Interim Storage Technology," DOE/ET-0028, December 1979.

5. United States Department of Energy, Technology for Cormercial

Radioactive Waste Management, Vo 1. 4: "Transportation, FinaT Disposal, Decommissioning and Thorium Fuel Cycle Considerations," DOE/ET-0028, May 1979.

6. United States Department of Energy, Technology for Commercial Radioactive Waste Management, Vo1. 5: "Waste Management System," DOE/ET-0028, May 1979.

7. United States Atomic Energy Commission, Radioactive Waste Management, Manual Chapter 0511, Government Printing Office, Washington, DC, September 19, 1973.

8. International Nuclear Fuel Cycle Evaluation, Waste Management and Disposal for Selected Nuclear Fuel Cycles, INFCE/WG.7/26, Vienna, May 1979.

9. United States Atomic Energy Commission, Environmental Survey of the Uranium Fuel Cycle, WASH-1248, April 1974.

10. Smith, R. I., G. J. Konzek, and W. E. Kennedy, Jr., Technology Safety and Costs of Decommissioning a Reference Pressurized Water Reactor Power Station, NUREG/CR-0130, Vol. 2, Append ix G, June 1978.

11. Manion, J. W. and T. S. Laguardia, An Engineering Evaluation of Nuclear Power Reactor Decommissioning Alternatives, AIF/NESP-009SR, November 1976. 


\section{ACKNOWLEDGMENTS}

The authors gratefully acknowledge the assistance of certain individuals in performing this study. R. W. Mckee, of Pacific Northwest Laboratory, and J. W. Voss, of the Office of Nuclear Waste Isolation operated by Battelle Memorial Institute, assisted in developing much of the data in this analysis. C. R. Cooley and D. L. Vieth, of the Department of Energy, and C. W. Kuhlman, formerly with DOE, assisted in interpreting and clarifying International Nuclear Fuel Cycle Evaluation bases and assumptions for use in this report. 
Allied General Nuclear Services, Barnwell Nuclear Fuel Plant, Final Safety Analys is Report. Docket 50-332, Barnwe11, SC, October 1973.

Allied General Nuclear Services, Draft Environmental Impact Statement. Docket 50-332, Barnwe11, SC, January $197 \overline{3}$.

Allied General Nuclear Services, Final Safety Analysis Report. Docket 50-332 Barnwe11, SC, October 10, 1973 (updated October 1975).

Allied General Nuclear Services, Uranium Hexafluoride Plant, Facility Safety Evaluation. Docket 70-1327, Barnwe11, SC, July 1972. ATso Draft Environmental Statement. Docket 70-1327, April 1974.

Atomic Energy Commission, Directorate of Licensing, Final Environmental Statement Related to Operation of Mixed Oxide Fabrication Plant, Exxon Nuclear Company. Docket 70-1257, June 1974.

Atomic Energy Commission, Directorate of Regulatory Standards, Final Environmental Statement Concerning Proposed Rule Making Action: Numerical Guides for Design Objectives and Limiting Conditions for Operation to Meet the Criterion 'As Low as Practicable' for Radioactive Material in Light-Water-Cooled Nuclear Power Reactor EffTuents, VoT. 1. WASH-1258, JuTy 1973.

Atomic Industrial Forum, A Survey and Evaluation of Handling and Disposal of Solid Low-Level Nuclear Fuel Cycle Wastes - AIF National Standards Project Report. AIF/NESP-008, October 1976.

Bel1, M. J., ORIGEN-The ORNL Isotope Generation and Population Code. ORNL-4628, Oak Ridge National Laboratory, Oak Ridge, TN, May 1973. (The cross sections used in the code have been calibrated so that the results meet the measured isotopes of spent nuclear power plant fuel.)

Blomeke, J. 0. and F. E. Harrington, Management of Radioactive Wastes at Nuclear Power Stations. ORNL-4070, Oak Ridge National Laboratory, Oak Ridge, TN, January 1968 .

B lomeke, J. 0. and J. J. Perona, Storage, Shipment, and Disposal of Spent Fuel Cladding. ORNL-TM-3650, Oak Ridge National Laboratory, Oak Ridge, TN, November 1972 .

Burger, L. L. and L. E. Trevorrow, "Release of Tritium from Fuel and Collection for Storage." In Proceedings of Topical Meeting on Controlling Airborne Effluents from Fuel Cycle Plants, American Nuclear Society and American Institute of Chemical Engineers, Sun Valley, ID, August 1976. 
Cooley, C. R., Commercial Alpha Waste Program Progress Report July-December 1975. HEDL-TME-76-22, Hanford Engineering Development Laboratory, RichTand, WA, May 1976.

Cooley, C. R., Commercial Alpha Waste Program Quarterly Progress Report January - March 1975. HEDL-TME-75-87, Hanford Engineering Deve lopment Laboratory, Richland, WA, October 1975.

Exxon Nuclear Co., Inc., Nuclear Fuel Recovery and Recycling Center Preliminary Safety Analysis Report. XN-FR-32, Docket 50-564, Richland, WA, 1976.

General Electric Co., Midwest Fuel Recovery Plant Environmental Impact Appraisal Re lated to License Amendment. Docket 70-1308-5, Morris, IL, December 1975.

General Electric Co., Safety Analysis Report, Midwest Fuel Recovery Plant. NEDO-10178, Morris, IL.

Godbee, H. W., Use of Evaporation for the Treatment of Liquids in the Nuc lear Industry. ORNL-4790, Oak Ridge National Laboratory, Oak Ridge, TN, September 1973.

Gray, J. H., E. W. Murbach, and A. K. Williams, "Experience and Plans for Effluent Control at LWR Fuel Reprocessing Plants." In Proceedings of Topical Meeting on Controlling Airborne Effluents from Fuel Cycle Plants, American Nuclear Society and American Institute of Chemical Engineers, Sun Valley, ID, August, 1976.

Griggs, B., Feasibility Studies for Decontamination and Densification of ChopLeach Residues. BNWL-1802, Battelle, Pacific Northwest Laboratories, Richland, WA, July 1974.

Gronier, W. S. et al., Correlation of Radioactive Waste Treatment Costs and the Environmental Impact of Waste Effluents in the Nuclear Fuel Cycle for Use in Establishing "As Low As Practicable" Guides - Fabrication of Light-Water Reactor Fuels Containing Plutonium. ORNL-TM-4904, Oak Ridge Nationa 1 Laboratory, Oak Ridge TN, May 1975.

Kee, C. W., A. G. Croft, and J. 0. Blomeke, Updated Projections of Radioactive Wastes to be Generated by the U.S. Nuclear Power Industry. ORNL-TM-5427, Oak Ridge Nationa] Laboratory, Oak Ridge, TN, December 1976.

Keely, R. B., "Description of Solid Waste Expected from a Large Commercial Reprocessing Plant." Presented at the Symposium on Management of Low-Leve Radioactive Wastes, Atlanta, GA, May 23-27, 1977.

Kerr-McGee Corp., Cimarron Plutonium Production Plant. Environmental Report, Supp lement 1. Docket 70-1193-6, December 1973. 
Levitz, N. M., B. J. Kullen, and M. J. Steindler, Management of Waste Cladding Hulls. Part I. Pyrophoricity and Compaction. ANL-8139, Argonne National Laboratory, Argonne, IL, February 1975.

Lin, K. H., Use of Ion Exchange for the Treatment of Liquids in Nuclear Power Plants. ORNL-4792, Oak Ridge National Laboratory, Oak Ridge, TN, December 1973.

Mulkin, R., Characterization of Transuranic Solid Wastes from a Plutonium Processing Facility. LA-5993-MS, Los Alamos Scientific Laboratory, Los Alamos, NM, June 1975.

Nuclear Fuel Services, Safety Analys is Report, NFS's Reprocessing Plant. Docket 50-201, West Valley, NY, 1973.

Nuc lear Regulatory Commission, Office of Standards Development, Calculation of Releases of Radioactive Materials in Gaseous and Liquid Effluents from Boiling Water Reactors (BWR-GALE Code). NUREG-0016, April 1976.

Nuclear Regulatory Commission, Office of Standards Development, Calculation of Releases of Radioactive Materials in Gaseous and Liquid Effluents from Pressurized Water Reactors (PWR-GALE Code). NUREG-0017, ApriT 1976.

Office of Nuclear Material Safety and Safeguards, Nuclear Regulatory Commission, "Mixed 0xide Fuel Fabrication." In Final Generic Environmental Statement on the Use of Recycle Plutonium in Mixed Oxide Fuel in Light Water Cooled Reactors. NUREG-0002, Vol. 3, Chapter IV, Section D, August 1976.

Steindler, M. J. and L. E. Trevorrow, "Description of the Fuel Cycle and Nature of the Wastes." In Proceedings of the International Symposium on the Management of Wastes from the LWR Fue T Cycle, CONF-76-0701, Denver, C0, JuTy 1976.

Trevorrow, L. E., B. J. Kullen, R. L. Jarry, and M. J. Steindler, Tritium and Noble Gas Fission Products in the Nuclear Fuel Cycle: Part I. Reactors. ANL-8102, Argonne National Laboratory, Argonne, IL, October 1974.

United States Energy Research and Development Administration, Alternatives for Managing Wastes from Reactors and Post-Fission Operations in the LWR Fuel Cycle, Vol. I through 5. ERDA 76-43, May 1976.

Westinghouse Electric Corporation, Nuclear Energy Systems, Source Term Data for Westinghouse Pressurized Water Reactors. WCAP-8523, May 1974.

Westinghouse Electric Corporation, Nuclear Fuel Division, Westinghouse Fuels Plant. Vol. 2. License Application. Docket 70-1432-2, October 12, 1973. 


\section{APPENDIX}

DETAILS OF ESTIMATED WASTE VOLUMES AND ACTIVITIES

FOR THE LWR U/PU RECYCLE FUEL CYCLE 
TABLE A-1. Estimated Operating Waste Volumes and Activities from the Reference Nuclear Power Plant (a)

\begin{tabular}{|c|c|c|c|c|c|c|c|}
\hline & \multirow{3}{*}{$\frac{\text { Waste Description }}{\text { Combustible trash }}$} & \multirow{2}{*}{\multicolumn{2}{|c|}{$\begin{array}{c}\text { Composition, } \\
\text { wt\% }\end{array}$}} & \multirow{2}{*}{\multicolumn{2}{|c|}{$\begin{array}{l}\text { Volume, } \mathrm{m}^{3} / \mathrm{GW}_{e} \cdot y \mathrm{r} \\
\text { As Generated As Shipped(b) }\end{array}$}} & \multicolumn{2}{|c|}{ Activity, $\mathrm{Cl} / \mathrm{GW} \cdot \mathrm{Wrr}^{(\mathrm{c})}$} \\
\hline & & & & & & Activation Products & Fisston Products \\
\hline & & Paper & 23 & 190 & 48 & $5.8 \mathrm{E}-1$ & $2.8 \mathrm{E} 0$ \\
\hline \multirow{4}{*}{$\frac{\text { Waste Stream }}{\text { General trash }}$} & & Plastic & 67 & & & & \\
\hline & & Rubber & 6 & & & & \\
\hline & & Wood & 3 & & & & \\
\hline & & Cloth & 1 & & & & \\
\hline \multirow[t]{10}{*}{ Wet waste } & Bead resins & Polystyrene & 50 & 27 & 43 & $1.7 \mathrm{E} 2$ & $3.9 \mathrm{E} 3$ \\
\hline & & $\mathrm{H}_{2} \mathrm{O}$ & 50 & & & & \\
\hline & Powdered resins & Polystyrene & 50 & 27 & 43 & $3.5 \mathrm{E} 2$ & $8.0 \mathrm{E} 1$ \\
\hline & & $\mathrm{H}_{2} \mathrm{O}$ & 50 & & & & \\
\hline & Filter precoat & Filter aids & 80 & 32 & 51 & $1.7 \mathrm{El}$ & $1.2 \mathrm{El}$ \\
\hline & sluage & $\mathrm{H}_{2} \mathrm{O}$ & 20 & & & & \\
\hline & Sulfate concentrate & $\mathrm{Na}_{2} \mathrm{SO}_{4}$ & 25 & 240 & 380 & 4.9E2 & $1.6 \mathrm{El}$ \\
\hline & & $\mathrm{H}_{2} \mathrm{O}$ & 75 & & & & \\
\hline & Borate concentrate & $\mathrm{Na}_{2} \mathrm{~B}_{4} \mathrm{O}_{7}$ & 10 & 4 & 6 & $5.6 \mathrm{E} 0$ & 4. OEO \\
\hline & & $\mathrm{H}_{2} \mathrm{O}$ & 90 & & & & \\
\hline \multirow[t]{3}{*}{ Scrap } & Noncombustible & Metal & 90 & 38 & 38 & $1.7 E-1$ & 8.0E-1 \\
\hline & $\operatorname{trash}$ & Glass & 10 & & & & \\
\hline & Control rods & Ferrous alloys & 100 & 6 & 7 & $1.9 \mathrm{ES}$ & $1.2 \mathrm{EO}$ \\
\hline \multicolumn{8}{|c|}{$\begin{array}{l}\text { (a) IWR, at equilibrium operation, } 2 / 3 \text { PWR - } 1 / 3 \text { BWR, } 1200 \mathrm{MW} \text { generating capacity, } 70 \% \text { load factor, } 30 \text { year } \\
\text { lifet ime, } 30,000 \text { MWd/MTHM average fuel exposure, } 32 \% \text { thermal-to-electric conversion efficiency, } 36.4 \mathrm{MTHM} / \mathrm{GW} \text { e } \mathrm{Yr} \text {, } \\
\text { approximately one-third of fuel is assumed to be mixed-oxide. } \\
\text { (b) As-shipped volume assumes the fol iowing treatments: } \\
\text { general trash - compaction } \\
\text { wet wastes - cement immobilization } \\
\text { scrap - direct packaging. } \\
\text { (c) Activities are at } 0.5 \text { year. }\end{array}$} \\
\hline
\end{tabular}


TABLE A-2. Estimated Maintenance Waste Volumes and Activities from the Ref erence Nuclear Power Plant (a)

\begin{tabular}{|c|c|c|c|c|c|c|c|}
\hline \multirow{3}{*}{$\begin{array}{l}\text { Waste Stream } \\
\text { General trash }\end{array}$} & \multirow{3}{*}{$\begin{array}{l}\text { Waste Description } \\
\text { HEPA filters }\end{array}$} & \multirow{2}{*}{\multicolumn{2}{|c|}{$\begin{array}{c}\text { Composition, } \\
\text { wt\% }\end{array}$}} & \multicolumn{2}{|c|}{ Volume, $m^{3} / G W_{e} \cdot y r$} & \multicolumn{2}{|c|}{ Activity, $\mathrm{Ci} / \mathrm{GW} \cdot \mathrm{yr}_{\mathrm{r}}$ (c) } \\
\hline & & & & Generate & As Shipped & ition Products & ducts \\
\hline & & Glass & 40 & 5 & 1.3 & $4.2 \mathrm{EO}$ & $3.2 E 0$ \\
\hline & & Wood & 60 & & & & \\
\hline Wet waste & Cartridge filters & Filter media & 80 & 5 & 7.5 & $3.5 \mathrm{E} 2$ & $2.0 E 0$ \\
\hline & & $\mathrm{H}_{2} \mathrm{O}$ & 20 & & & & \\
\hline
\end{tabular}

(a) See Table $A-1$, footnote (a).

(b) See Table A-l, footnote (b).

(c) Activities are at 0.5 year. 
TABLE A-3. Estimated Waste Volumes and Activities for Ent ombment of the Reference Nuclear Power Plant (a)

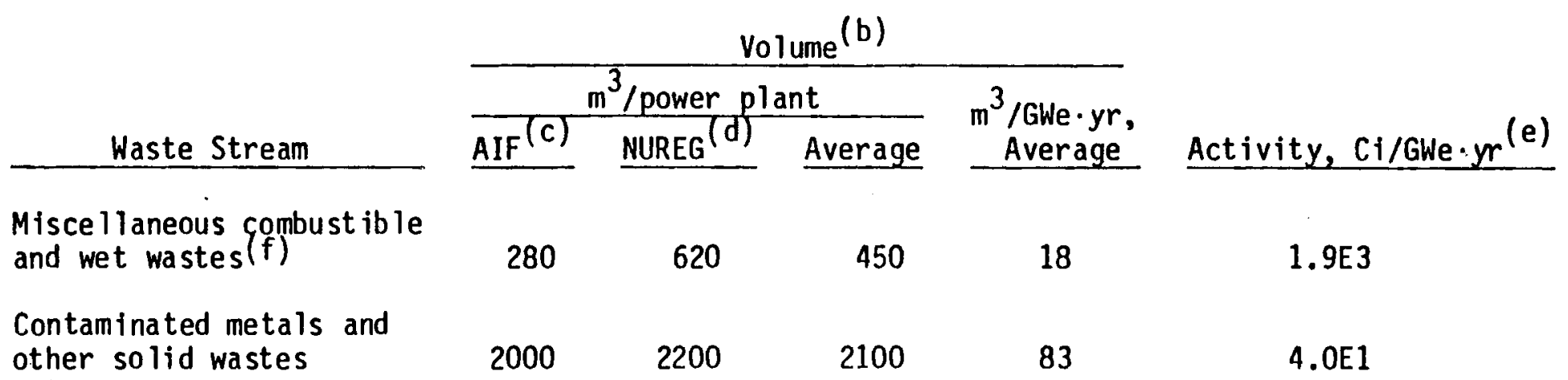

(a) See Table A-l, footnote (a).

(b) Volumes presented assume that combust ible wastes are compacted, wet wastes are immobilized. in cement, and solid wastes are packaged directly.

(c) Est imated from data presented in Reference 11.

(d) Est imated from data presented in Reference 10, specifically, from Table G.4-2, It was assumed that $50 \%$ of the "contaminated metals and misc." and all of the "radioactive wastes" are packaged and shipped to the repository. The other wastes are assumed to be deposited with in the entombment structure.

(e) Est imated from Reference 10. Activities are at time of shutdown, and are primarily activation products.

(f) E.g., decontamination wastes, ion exchange resins, cartridge filters, evaporator bottoms. 

TABLE A-4. Estimated Operating Waste Volumes and Actiyifies
from the Reference Fuel Reprocessing Plant

\begin{tabular}{|c|c|c|c|c|c|c|c|c|c|}
\hline \multirow[b]{2}{*}{ Haste Stream } & \multirow[b]{2}{*}{ Haste Description } & \multirow{2}{*}{\multicolumn{2}{|c|}{$\begin{array}{c}\text { Composition, } \\
\text { wtx }\end{array}$}} & \multirow[b]{2}{*}{$\begin{array}{r}\text { Volume, } \\
\text { As Generated }\end{array}$} & \multirow[b]{2}{*}{$\frac{\mathrm{m}^{3} / G \mathrm{~W}_{e} \cdot \mathrm{yr}}{\mathrm{As} \text { Shipped (D) }}$} & \multicolumn{4}{|c|}{ Activity, $C 1 / G H_{e} \cdot y r(c)$} \\
\hline & & & & & & $\begin{array}{l}\text { Fission } \\
\text { Products }\end{array}$ & U & Pu & $\begin{array}{c}\text { Other } \\
\text { Actinides }\end{array}$ \\
\hline IRU & & & & & & & & & \\
\hline & & Meoprene & 11 & & & & & & \\
\hline & & Polyethylene & 14 & & & & & & \\
\hline & & Latex & 11 & & & & & & \\
\hline & & Hood & 4 & & & & & & \\
\hline & $\begin{array}{l}\text { Pu0 } 2 \text { conversion } \\
\text { combust tible trash }\end{array}$ & Same as above & & 1.1 & 0.2 & NS & NS & $\begin{array}{l}3.3 \mathrm{E} 3^{\circ} \\
(2.2 \mathrm{Eg})\end{array}$ & RS \\
\hline & Ion exchange bead resins & Polystyrene & 50 & 0.2 & 0.05 & $3.4 E 2$ & $2.0 E-3$ & $6.8 E 1$ & $2.0 E-1$ \\
\hline & & $\mathrm{H}_{2} \mathrm{O}$ & 50 & & & & & & \\
\hline & Degraded extractant & TBP & $30(\mathrm{vol})$ & 0.3 & 0.08 & $1.2 \mathrm{E} 2$ & $2.0 E-4$ & $6.8 E 2$ & 2.060 \\
\hline & & n-dodecane & $10(v 01)$ & & & & & & \\
\hline & & $\mathrm{Ne}_{3} \mathrm{PO}_{4}$ & $B$ & & & & & & \\
\hline & & Misc. saits & 4 & & & & & & \\
\hline & & $\mathrm{H}_{2} \mathrm{O}$ & 70 & & & & & & \\
\hline & Main plant sillea gel & $\mathrm{SiO}_{2}$ & 70 & 0.2 & 0.3 & 1.960 & NS & $6.8 \mathrm{E}-1$ & NS \\
\hline & & $\mathrm{H}_{2} \mathrm{O}$ & 30 & & & & & & \\
\hline & $\begin{array}{l}\text { Uf } 6 \text { plant fluorinator } \\
\text { bed residues }\end{array}$ & $\mathrm{Al}_{2} \mathrm{O}_{3}$ & 100 & 0.2 & 0.3 & 1.760 & $\begin{array}{c}1.2 E-3 \\
(2.2 E 2 g)\end{array}$ & $\begin{array}{l}1.3 E 0 \\
(8.8 E-2 g)\end{array}$ & NS \\
\hline & Uf 6 plant fluorinator & $\mathrm{Al}_{2} \mathrm{O}_{3}$ & 50 & 1.1 & 1.8 & $1.7 \mathrm{E} 1$ & 3.0E-1 & $6.8 \mathrm{EO}$ & NS \\
\hline & & $\mathrm{CoF}_{2}$ & 46 & & & & & & \\
\hline & & $\begin{array}{l}\text { Uranlum } \\
\text { fluorides }\end{array}$ & 4 & & & & & & \\
\hline Serap & $\begin{array}{l}\text { Main plant noncombus- } \\
\text { tible trash }\end{array}$ & $\begin{array}{l}\text { Ferrous } \\
\text { alloys }\end{array}$ & 90 & 15 & 15 & $1.2 E 2$ & $\begin{array}{c}2.0 E-4 \\
(3.6 E 1 g)\end{array}$ & $\begin{array}{l}6.8 E 0 \\
(4.4 E-19)\end{array}$ & $2.1 E 0$. \\
\hline & & Glass & 10 & & & & & & \\
\hline & $\begin{array}{l}\text { UF } 6 \text { plant noncombus- } \\
\text { tible trash }\end{array}$ & Same as above & & 0.4 & 0.4 & NS & $\begin{array}{c}2.0 E-2 \\
(3.6 E 3 g)\end{array}$ & NS & NS \\
\hline
\end{tabular}


TABLE A-4. (contd)

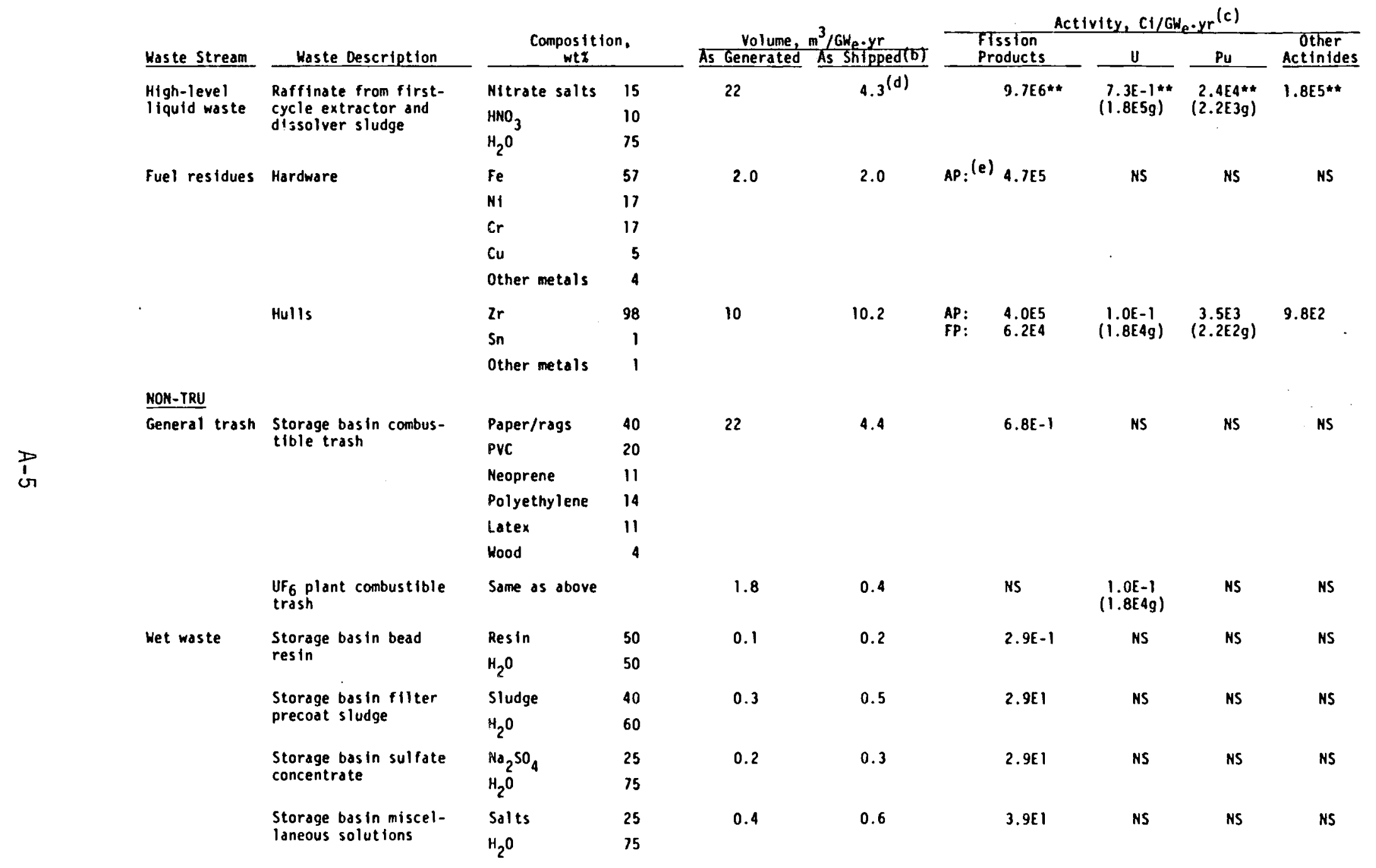


TABLE A-4. (contd)

\begin{tabular}{|c|c|c|c|c|c|c|c|c|c|}
\hline \multirow{8}{*}{ Waste Stream } & \multirow[b]{2}{*}{ Waste Description } & \multirow{2}{*}{\multicolumn{2}{|c|}{$\underset{w t x}{\text { Composition. }}$}} & \multirow{2}{*}{\multicolumn{2}{|c|}{$\frac{\text { Volume, }}{\text { As Generated }} \frac{m^{3} / G W_{e} \cdot y r}{A s \text { Shipped(b) }}$}} & \multicolumn{4}{|c|}{ Activity, $\mathrm{Cl} / \mathrm{GW}_{\mathrm{e}} \cdot \mathrm{yr}(\mathrm{c})$} \\
\hline & & & & & & $\begin{array}{l}\text { Fission } \\
\text { Products }\end{array}$ & $\mathbf{u}$ & Pu & $\begin{array}{l}\text { Other } \\
\text { Actinides }\end{array}$ \\
\hline & $\mathrm{UF}_{6}$ plant $\mathrm{K}_{2} \mathrm{UO}_{4}$ mud & $\mathrm{KOH}$ & 3 & 2.6 & 4.2 & MS & $2.6 E-1$ & NS & NS \\
\hline & & $\mathbf{K F}$ & 4 & & & & & & \\
\hline & & $\mathrm{K}_{2} \mathrm{UO}_{4}$ & 3 & & & & & & \\
\hline & & $\mathrm{Fe}(\mathrm{OH})_{2}$ & 18 & & & & & & \\
\hline & & Misc. Salts & 1 & & & & & & \\
\hline & & $\mathrm{H}_{2} \mathrm{O}$ & 71 & & & & & & \\
\hline Scrop & Storage basin noncom- & Ferrous alloys & 90 & 1.8 & 1.8 & $A P:(e) 9.9 E-3$ & NS & NS & NS \\
\hline & bustible trash & Glass & 10 & & & & & & \\
\hline
\end{tabular}

(a) The fuel reprocessing plant is assumed to be of conventional design based on the PUREX flowsheet, with a nominal throughput of 2000 MTHM/yr,

(b) See Table A-l. footnote (b). Additionally, high-level liquid waste as-shipped volume assumes vitriflcation and fuel residues as-shipped

volumes assumes cementation of uncompacted hull and hardware.

(c) Activities are at 0.5 year except as noted: indicates 1.5 years; * Indicates 10 years.
(d) Volume of waste glass only; packaged volume is greater by $1.25 x$.

(e) AP: activation products: FP: fission products. 
TABLE A-5. Estimated Maintenance Waste Volumes and Actiyities from the Reference Fuel Reprocessing Plant $(a)$

\begin{tabular}{|c|c|c|c|c|c|c|c|c|c|}
\hline \multirow[b]{2}{*}{ Waste Stream } & \multirow[b]{2}{*}{ Waste Description } & \multirow{2}{*}{\multicolumn{2}{|c|}{$\begin{array}{c}\text { Composition, } \\
\text { wtx }\end{array}$}} & \multirow{2}{*}{\multicolumn{2}{|c|}{$\frac{\text { Volume, } \mathrm{m}^{3} / \mathrm{GW}_{\mathrm{e}} \cdot \mathrm{yr}}{\text { As Generated As Shipped }}$}} & \multicolumn{4}{|c|}{ Activity, $\mathrm{Cl} / \mathrm{GW}_{\mathrm{e}} \cdot \mathrm{yr}(\mathrm{c})$} \\
\hline & & & & & & $\begin{array}{l}\text { Fission } \\
\text { Products }\end{array}$ & $\underline{U}$ & Pu & $\begin{array}{c}\text { Other } \\
\text { Actinides }\end{array}$ \\
\hline \multicolumn{10}{|l|}{ IRU } \\
\hline \multirow[t]{2}{*}{ General trash } & $\begin{array}{l}\text { Main plant ventilation } \\
\text { filters }\end{array}$ & $\begin{array}{l}\text { Wood } \\
\text { Glass }\end{array}$ & $\begin{array}{l}60 \\
40\end{array}$ & 5.1 & 1.3 & $1.2 \mathrm{E} 3$ & $\begin{array}{c}2.0 \mathrm{E}-3 \\
(3.5 \mathrm{E} 2 \mathrm{~g})\end{array}$ & $\begin{array}{l}6.9 \mathrm{El} \\
(4.4 \mathrm{EOg})\end{array}$ & $2.0 \mathrm{EI}$ \\
\hline & $\begin{array}{l}\mathrm{PuO}_{2} \text { conversion ventila- } \\
\text { tion filters }\end{array}$ & $\begin{array}{l}\text { Metal } \\
\text { Glass }\end{array}$ & $\begin{array}{l}60 \\
40\end{array}$ & 0.7 & 0.2 & NS & NS & $\begin{array}{l}1.3 \mathrm{E} 4^{\star} \\
(8.8 \mathrm{E} 2 \mathrm{~g})\end{array}$ & NS \\
\hline \multirow[t]{3}{*}{ Scrap } & $\begin{array}{l}\text { Main plant foiled } \\
\text { equipment }\end{array}$ & Ferrous alloys & 100 & 7.3 & 7.3 & $1.2 \mathrm{E} 2$ & $\begin{array}{l}2.0 \mathrm{E}-4 \\
(3.6 \mathrm{E} / \mathrm{g})\end{array}$ & $\begin{array}{l}6.9 E 0 \\
(4.4 E-1 g)\end{array}$ & $2.0 \mathrm{EO}$ \\
\hline & $\begin{array}{l}\text { UF }_{6} \text { plant falled } \\
\text { equipment }\end{array}$ & Same as above & & 0.4 & 0.4 & NS & $\begin{array}{l}2.0 \mathrm{E}-3 \\
(3.6 \mathrm{E} 2 \mathrm{~g})\end{array}$ & NS & NS \\
\hline & $\begin{array}{l}\mathrm{PuO}_{2} \text { conversion failed } \\
\text { equipment }\end{array}$ & Same as above & & 0.8 & 0.8 & NS & NS & $\begin{array}{l}6.9 \mathrm{E2}{ }^{\star} \\
(4.4 \mathrm{Elg})\end{array}$ & NS \\
\hline \multicolumn{10}{|l|}{ NON-TRU } \\
\hline \multirow[t]{2}{*}{ General trash } & $\begin{array}{l}\text { Storage basin ventila- } \\
\text { tlon filters }\end{array}$ & $\begin{array}{l}\text { Wood } \\
\text { Glass }\end{array}$ & $\begin{array}{l}60 \\
40\end{array}$ & 0.4 & 0.1 & $2.6 E \mathrm{~J}$ & NS & NS & NS \\
\hline & $\begin{array}{l}\text { UF } 6 \text { plant ventilation } \\
\text { filters }^{-}\end{array}$ & Same as above & & 0.2 & 0.05 & NS & $\begin{array}{l}2.0 \mathrm{E}-3 \\
(3.6 \mathrm{E} 2 \mathrm{~g})\end{array}$ & NS & NS \\
\hline Scrap & $\begin{array}{l}\text { Storage basin falled } \\
\text { equipment }\end{array}$ & Ferrous alloys & 100 & 0.4 & 0.4 & $\begin{array}{ll}A P: & \text { (d) } \\
\text { FP: } & 3.3 E-3 \\
\text { A.OE-2 }\end{array}$ & NS & NS & NS \\
\hline $\begin{array}{l}\text { (a) See Table } \\
\text { (b) See Table } \\
\text { (c) Activities } \\
\text { (d) AP: activ }\end{array}$ & $\begin{array}{l}\text { A-4, footnote (a). } \\
\text { A-1, footnote (b). } \\
\text { are at } 0.5 \text { year except a } \\
\text { ation products; FP: fiss }\end{array}$ & $\begin{array}{l}\text { noted: } \text { indica } \\
\text { products. }\end{array}$ & & & & & & & \\
\hline
\end{tabular}


TABLE A-6. Estimated Waste Volumes and Activities for Protective Storage/ Dismantlement of the Reference Fuel Reprocessing Plant $(a)$

\begin{tabular}{|c|c|c|c|c|c|c|c|c|}
\hline & & & & & & Activity, $C$ & $1 / G W_{e} \cdot y r^{(d)}$ & \\
\hline Haste Stream & Waste Description & $\begin{array}{l}\text { Decommissfondng } \\
\text { Phase(b) }\end{array}$ & $\begin{array}{l}\text { Volume, } \\
\text { As Generated }\end{array}$ & $\frac{m^{3} / G W_{e} \cdot y r}{\text { As Shipped(c) }}$ & $\begin{array}{l}\text { Fission } \\
\text { Products } \\
\end{array}$ & 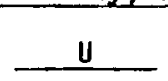 & Pu & $\begin{array}{c}\text { other } \\
\text { Act inides }\end{array}$ \\
\hline TRU & & & & & & & & \\
\hline General trash & Combustible trash & PS & 0.06 & 0.02 & B. $3 E-4$ & $\begin{array}{l}1.3 E-8 \\
(2.2 E-2 g)\end{array}$ & $\begin{array}{l}2.0 E-4 \\
(8.4 E-5 g)\end{array}$ & $5.2 E-5$ \\
\hline & Combusttble trash & D & 0.08 & 0.02 & $4.6 E-3^{\star}$ & $\begin{array}{c}5.8 E-8 * \\
(4.6 E-2 g)\end{array}$ & $\begin{array}{l}1.6 \mathrm{E}-3 \star \\
(1.9 \mathrm{E}-4 \mathrm{~g})\end{array}$ & $1.4 E-4 *$ \\
\hline & HEPA fllters & PS & 0.10 & 0.27 & $5.8 E-1$ & $\begin{array}{l}9.1 \mathrm{E}-6 \\
(1.6 \mathrm{E} / \mathrm{g})\end{array}$ & $\begin{array}{l}1.4 \mathrm{E}-1 \\
(5.9 \mathrm{E}-2 \mathrm{~g})\end{array}$ & $3.6 \mathrm{E}-2$ \\
\hline & HEPA filters & PS & 0.02 & 0.05 & NS & $\begin{array}{c}1.6 \mathrm{E}-5 \\
(2.8 \mathrm{E} \mathrm{gg})\end{array}$ & $\begin{array}{l}2.4 E-1 \\
(1.1 E-19)\end{array}$ & $6.5 E-2$ \\
\hline . & HEPA filters & D & 0.10 & 0.27 & $5.8 E-2$ & $\begin{array}{l}9.1 \mathrm{E}-7 \\
(1.6 \mathrm{EOg})\end{array}$ & $\begin{array}{l}1.4 \mathrm{E}-2 \\
(5.9 \mathrm{E}-3 \mathrm{~g})\end{array}$ & $3.6 \mathrm{E}-3$ \\
\hline & HEPA filters & D & 0.02 & 0.05 & NS & $\begin{array}{c}1.6 \mathrm{E}-6 \\
(2.8 \mathrm{E} 0 \mathrm{~g})\end{array}$ & $\begin{array}{l}2.4 E-2 \\
(1.1 E-2 g)\end{array}$ & $6.5 E-3$ \\
\hline Wet waste & $\begin{array}{l}\text { Noncombustible wet } \\
\text { wastes }\end{array}$ & PS & 0.14 & 0.22 & $4.8 E-1$ & $\begin{array}{l}7.5 E-6 \\
(1.3 E I g)\end{array}$ & $\begin{array}{l}1.1 E-1 \\
(4.9 E-2 g)\end{array}$ & $3.0 \mathrm{E}-2$ \\
\hline Scrap & $\begin{array}{l}\text { Equipment and structural } \\
\text { materials }\end{array}$ & 0 & 0.11 & 0.11 & $1.3 \mathrm{EO}$ & $\begin{array}{c}2.0 E-5 \\
(3.3 E 19)\end{array}$ & $\begin{array}{l}2.9 E-1 \\
(1.3 E-1 g)\end{array}$ & $7.8 E-2$ \\
\hline & $\begin{array}{l}\text { Equipment and structural } \\
\text { materials }\end{array}$ & 0 & 0.47 & 0.47 & $5.4 E-1$ & $\begin{array}{l}8.4 E-6 \\
(1.4 E \lg )\end{array}$ & $\begin{array}{l}1.3 \mathrm{E}-1 \\
(5.5 \mathrm{E}-2 \mathrm{~g})\end{array}$ & $3.4 E-2$ \\
\hline & $\begin{array}{l}\text { Equipment and structural } \\
\text { materials }\end{array}$ & D & 0.73 & 0.73 & $4.2 E-1$ & $\begin{array}{l}6.5 E-6 \\
(1.1 E I g)\end{array}$ & $\begin{array}{c}9.7 \mathrm{E}-2 \\
(4.2 \mathrm{E}-2 \mathrm{~g})\end{array}$ & $2.6 \mathrm{E}-2$ \\
\hline NON-TRU & & & & & & & & \\
\hline General trash & Combustible trash & PS & 0.04 & 0.01 & $5.0 E-4$ & NS & NS & NS \\
\hline & Combustible trash & PS & 0.07 & 0.02 & $9.9 E-4^{*}$ & NS & NS & NS \\
\hline & Combusttble trash & D & 0.06 & 0.01 & $1.2 \mathrm{E}-3$ & NS & NS & NS \\
\hline & MEPA filters & PS & 0.02 & 0.01 & 8. 3E-2 & NS & NS & NS \\
\hline & HEPA filters & D & 0.02 & 0.01 & 8. $3 E-3$ & NS & NS & NS \\
\hline
\end{tabular}


TABLE A-6. (contd)

\begin{tabular}{|c|c|c|c|c|c|c|c|c|}
\hline \multirow[b]{2}{*}{ Waste Stream } & \multirow[b]{2}{*}{ Waste Description } & \multirow[b]{2}{*}{$\begin{array}{c}\text { Decomissignting } \\
\text { Phase }(b)^{-}\end{array}$} & \multirow[b]{2}{*}{$\begin{array}{r}\text { Volume, } \\
\text { As Generated }\end{array}$} & \multirow[b]{2}{*}{$\begin{array}{l}\mathrm{m}^{3} / \mathrm{GW} \\
\text { As Shipr }\end{array}$} & \multicolumn{4}{|c|}{ Activity, Ci/GW $\cdot y r^{(d)}$} \\
\hline & & & & & $\begin{array}{l}\text { Fission } \\
\text { Products }\end{array}$ & $\mathbf{U}$ & Pu & $\begin{array}{c}\text { other } \\
\text { Actinides }\end{array}$ \\
\hline \multirow[t]{2}{*}{ Wet waste } & Combustible wet wastes & PS & 0.08 & 0.13 & $2.9 E-1$ & NS & NS & NS \\
\hline & $\begin{array}{l}\text { Noncombustible wet } \\
\text { wastes }\end{array}$ & PS & 0.04 & 0.06 & $1.3 E-1$ & NS & N5 & NS \\
\hline \multirow[t]{2}{*}{ Scrap } & $\begin{array}{l}\text { Equipment and structural } \\
\text { materials }\end{array}$ & D & 0.11 & 0.11 & $6.2 E-2$ & NS & NS & NS \\
\hline & $\begin{array}{l}\text { Equipment and structural } \\
\text { materials }\end{array}$ & D & 3.6 & 3.6 & 8. $3 E-2$ & NS & NS & NS \\
\hline $\begin{array}{l}\text { (a) See Table } \\
\text { (b) Indicates } \\
\text { (c) See Table } \\
\text { (d) Activities }\end{array}$ & $\begin{array}{l}-4 \text {, footnote (a): the faci } \\
\text { ecomissioning phase durin } \\
-1 \text {, footnote (b). } \\
\text { are at time of shutdown }+\end{array}$ & $\begin{array}{l}\text { lity is placed in } \\
9 \text { which the was te } \\
30 \text { years except a }\end{array}$ & $\begin{array}{l}30 \text {-year prote } \\
\text { is generated } \\
5 \text { noted: }\end{array}$ & $\begin{array}{l}\text { ective storage } p \\
\text {; } P \text { : protective } \\
\text { dicates activity }\end{array}$ & $\begin{array}{l}\text { rior to di } \\
\text { storage; } 0 \\
\text { at shutdo }\end{array}$ & & & . \\
\hline
\end{tabular}




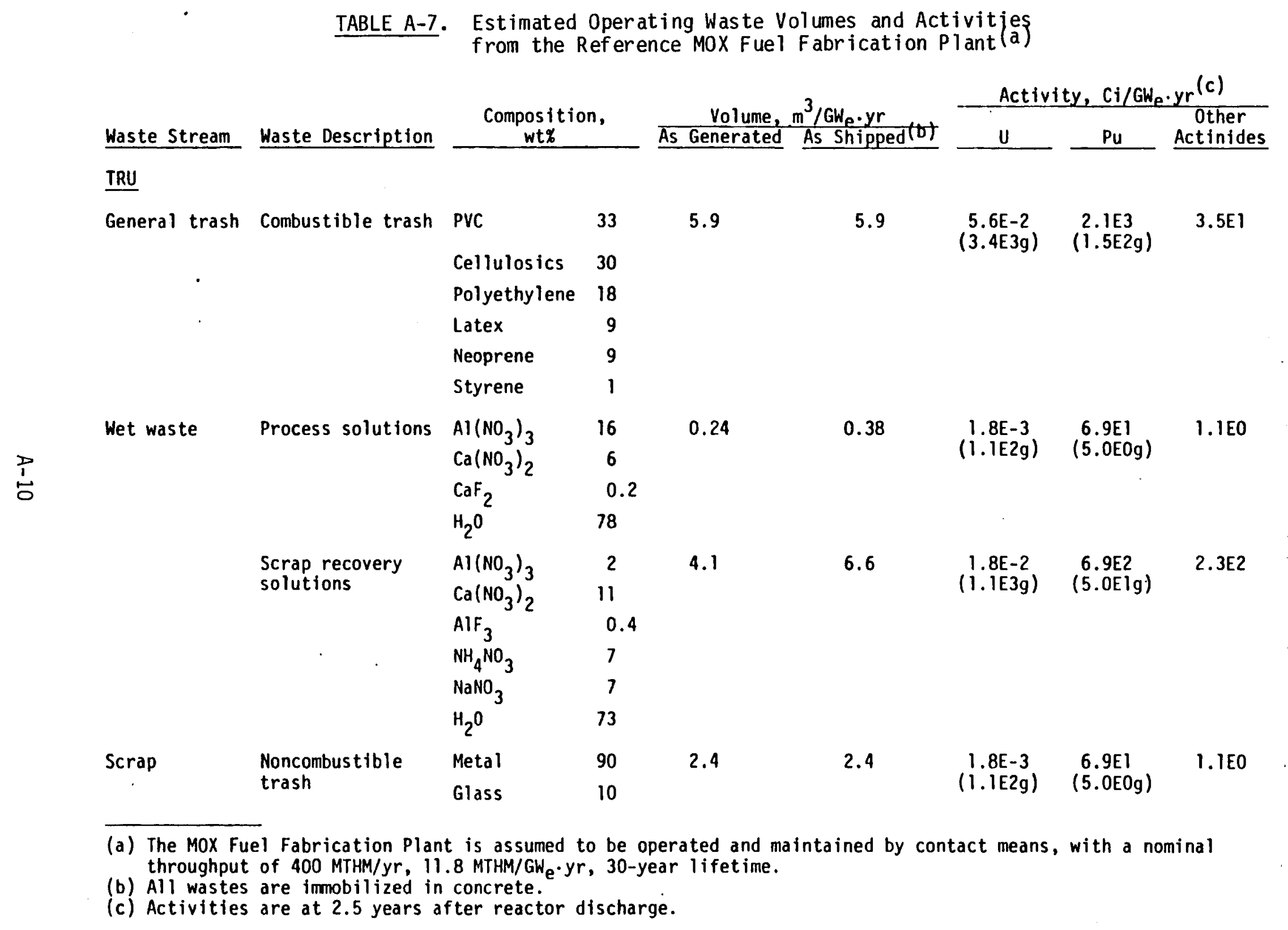


IABLE A-8. Estimated Maintenance Waste Volumes and Activjtjes

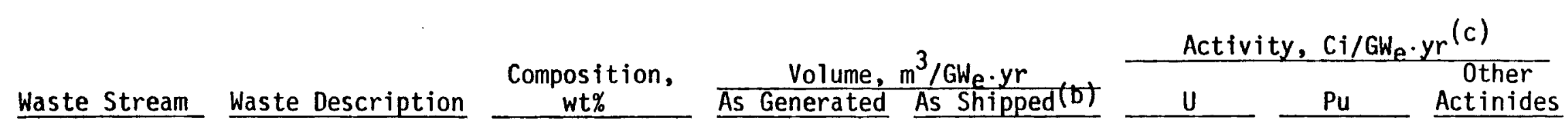

TRU

General trash

HEPA filters

Metal $60 \quad 1.2$

1.2

1. $3 \mathrm{E}-1$

4.9E3

Glass $\quad 40$

Scrap

Failed equipment

Metal 80

2.4

2.4

(7.8E3g)

(3.3E2g)

Insulating 20 brick

20

$1.8 \mathrm{E}-3$

$6.9 \mathrm{El}$

$(1.1 \mathrm{E} 2 \mathrm{~g})$

(5.0EOg)

8.0E1

$1.1 E 0$

\footnotetext{
(a) See Table A-7, footnote (a).

(b) All wastes are immobilized in concrete.

$\models$ (c) Activities are at 2.5 years after reactor discharge.
} 
TABLE A-9. Estimated Waste Volumes and Activities from Djsmantlement of the Reference MOX Fuel Fabrication Plant (a)

\begin{tabular}{|c|c|c|c|c|c|c|c|}
\hline \multirow[b]{2}{*}{ Waste Stream } & \multirow[b]{2}{*}{ Waste Description } & \multirow[b]{2}{*}{$\begin{array}{l}\text { Decommissioning } \\
\text { Phase (b) } \\
\end{array}$} & \multirow{2}{*}{\multicolumn{2}{|c|}{ Volume, $\mathrm{m}^{3} / \mathrm{GW}_{\mathrm{e}} \cdot \mathrm{yr}$}} & \multicolumn{3}{|c|}{ Activity, Ci/GWe.yr ${ }^{(d)}$} \\
\hline & & & & $\begin{array}{l}\frac{\mathrm{m} / G W_{e} \cdot y r}{\text { As Shipped(c) }} \\
\text { L }\end{array}$ & U & $\mathrm{Pu}$ & $\begin{array}{c}\text { Other } \\
\text { Actinides } \\
\end{array}$ \\
\hline \multicolumn{8}{|l|}{ TRU } \\
\hline \multirow[t]{2}{*}{ General trash } & Combustible trash & D & $9.8 \mathrm{E}-2$ & $1.5 \mathrm{E}-2$ & $\begin{array}{c}7.6 \mathrm{E}-5 \\
(6.5 \mathrm{E} 0 \mathrm{~g})\end{array}$ & $\begin{array}{l}2.5 \mathrm{E} 0 \\
(2.7 \mathrm{E}-1 \mathrm{~g})\end{array}$ & $5.4 E-2$ \\
\hline & HEPA filters & D & $2.4 E-2$ & $6.4 E-2$ & $\begin{array}{c}2.8 \mathrm{E}-3 \\
(2.4 \mathrm{E} 2 \mathrm{~g})\end{array}$ & $\begin{array}{l}9.2 \mathrm{El} \\
(1.0 \mathrm{E} \lg )\end{array}$ & $\begin{array}{r}1.9 \mathrm{EO} \\
i\end{array}$ \\
\hline \multirow[t]{2}{*}{ Wet waste } & $\begin{array}{l}\text { Combustible wet } \\
\text { wastes }\end{array}$ & D & 2.0E-1 & $3.1 E-2$ & $\begin{array}{l}1.1 \mathrm{E}-3 \\
(9.6 \mathrm{E}] \mathrm{g})\end{array}$ & $\begin{array}{l}3.7 \mathrm{El} \\
(4.0 \mathrm{EOg})\end{array}$ & $7.8 E-1$ \\
\hline & $\begin{array}{l}\text { Noncombustible wet } \\
\text { wastes }\end{array}$ & D & $9.8 \mathrm{E}-2$ & $1.6 \mathrm{E}-1$ & $\begin{array}{l}6.9 \mathrm{E}-6 \\
(5.9 \mathrm{E}-1 \mathrm{~g})\end{array}$ & $\begin{array}{l}2.3 \mathrm{E}-1 \\
(2.5 \mathrm{E}-2 \mathrm{~g})\end{array}$ & $4.9 E-3$ \\
\hline \multirow[t]{3}{*}{ Scrap } & $\begin{array}{l}\text { Equipment and } \\
\text { structural } \\
\text { materials }\end{array}$ & D & $2.9 E-1$ & $2.9 \mathrm{E}-1$ & $\begin{array}{l}1.4 \mathrm{E}-3 \\
(1.2 \mathrm{E} 2 \mathrm{~g})\end{array}$ & $\begin{array}{l}4.6 \mathrm{El} \\
(5.0 \mathrm{EOg})\end{array}$ & $9.8 \mathrm{E}-1$ \\
\hline & $\begin{array}{l}\text { Equipment and } \\
\text { structural } \\
\text { materials }\end{array}$ & D & $1.8 \mathrm{E} 0$ & $1.8 \mathrm{EE}$ & $\begin{array}{l}1.4 \mathrm{E}-3 \\
(1.3 \mathrm{E} 2 \mathrm{~g})\end{array}$ & $\begin{array}{l}4.8 \mathrm{El} \\
(5.2 \mathrm{EOg})\end{array}$ & 1.0EO \\
\hline & $\begin{array}{l}\text { Equipment and } \\
\text { structural } \\
\text { materials }\end{array}$ & D & $2.9 E-1$ & $2.9 \mathrm{E}-1$ & $\begin{array}{l}1.4 \mathrm{E}-4 \\
(1.2 \mathrm{E} 7 \mathrm{~g})\end{array}$ & $\begin{array}{l}4.6 \mathrm{EO} \\
(5.0 \mathrm{E}-1 \mathrm{~g})\end{array}$ & $9.8 E-2$ \\
\hline
\end{tabular}

\footnotetext{
(a) See Table A-7, footnote (a); the facility is dismantled upon shutdown.

(b) See Table A-3, footnote (b).

(c) See Table A-1, footnote (b).

(d) Activities are at time of shipment from site.
} 


\section{DISTRIBUTION}

No. of

Copies

OFFSITE

UNITED STATES

A. A. Churm

DOE Chicago Patent Group

9800 South Cass Avenue

Argonne, IL 60439

27 DOE Technical Information Center

R. E. Cunningham

Office of Nuclear Safety Materials and Safeguards

Room 562

Nuclear Regulatory Commission

7915 Eastern Avenue

Silver Springs, MD 20910

2 Division of Waste Management Nuclear Regulatory Commission Washington, DC 20555

ATTN: J. B. Martin

R. Dale Smith

D. M. Rohrer

High-Level Waste Technical Development

Nuclear Regulatory Commission

Washington, DC 20555

W. E. Mott

DOE Division of Environmenta]

Control Technology

Washington, DC 20545

10 DOE Office of Nuclear Waste Management

NEW, B-107, HQ

Washington, DC 20545

ATTN: C. R. Cooley

C. A. Heath

M. J. Lawrence

E. F. Mastal

G. Oertel

A. F. Perge

R. W. Ramsey, Jr.

V. G. Trice

D. L. Vieth

E. Wah lquist

J. 0. Neff

Department of Energy Columbus Program Office

$505 \mathrm{King}$ Avenue

Columbus, $\mathrm{OH} 43201$
No. of

Copies

J. W. Peel

DOE Idaho Operations Office

550 2nd St.

Idaho Falls, ID 83401

D. Large

DOE Operations Office

P.0. Box E

Oak Ridge, TN 37830

4 Oak Ridge National Laboratory P.O. Box $Y$

Oak Ridge, TN 37830

ATTN: R. E. Blanco

J. 0. Blomeke

R. S. Lowrie

K. Notz

2 DOE Savannah River Operations Office

P.0. Box A

Aiken, SC 29801

ATTN: E. S. Goldberg

R. P. Whitfield

3 Exxon Nuclear Idaho

P.0. Box 2800

Idaho Falls, ID 83401

ATTN: G. L. Ritter

R. A. Brown

File Copy

G. B. Levin

EG\&G Idaho

P.0. Box 1625

Idaho Falls, ID 83415

A. L. Taboas

TRU Waste Management Program

DOE Albuquerque Operations Office

P.0. Box 5400

Aibuquerque, NM 87185

2 Allied-General Nuclear Services P.0. Box 847

Barnwell, SC 29812

ATTN: J. A. Buckham

A. Williams

2 Argonne National Laboratory 9700 South Cass Avenue Argonne, IL 60439

ATTN: J. L. Jardine M. J. Steindler/

L. E. Trevorrow 
No. of

Copies

5 Battelle Memorial Institute Office of Nuclear Waste I solation $505 \mathrm{King}$ Avenue Columbus, $\mathrm{OH} 43201$

ATTN: N. E. Carter

P. L. Hofmann

M. Kehnemuyi

Beverly Rawles

J. W. Voss

L. J. Smith

TRU Waste Systems Office

B1dg. T-790

Rockwe 11 International

Rocky Flats Plant

P.0. Box 464

Golden, CO 80401

4 E. I. Du Pont de Nemours Co. Savannah River Laboratory

Aiken, SC 29801

ATTN: H. H. Baker

J. L. Cranda 11

R. G. Garvin

P. H. Permar

R. Williams

Electric Power Research Institute 3412 Hillview Avenue

P.0. Box 10412

Palo Alto, CA 94304

Environmental Protection Agency Technology Assessment Division (AW-559)

Office of Radiation Programs

U.S. Environmental Protection Agency

Washington, DC 20460

W. Weart

Division 1140

Sandia Laboratories

Albuquerque, NM 87185

J. W. Bartlett

The Analytical Sciences Corp.

6 Jacob Way

Reading, MA 01867

R. E. Burns

2412 Cedar Park Drive

Port Angeles, WA 98362

F. K. Pittman

3508 Sagecrest Terrace

Ft. Worth, TX 76109

\section{ONSITE}

8 DOE Richland Operations Office

E. A. Bracken
No. of

Copies
P. A. Craig
0. J. Elgert
R. E. Gerton
H. E. Ransom
J. J. Schreiber
M. W. Shupe
M. J. Zamorski

5 Rockwe 11 Hanford Operations
L. C. Brown
R. A. Deju
R. J. Gimera
J. H. Roecker
D. D. Wodrich

2 UNC United Nuclear Industries

T. E. Dabrowski

J. F. Nemec

Westinghouse Hanford Company
A. G. Blasewitz

39 Pacific Northwest Laboratory

D. B. Cear lock

T. D. Chikalla

F. H. Dove

R. M. Fleischman

A. J. Haverfield/W. R. Wiley

O. F. Hill

J. H. Jarrett

M. R. Kreiter

L. T. Lakey

D. E. Larson

R. C. Liikala

R. P. Marshall

J. L. McElroy

R. H. McKee

J. E. Mende 1

E. T. Merr 111

I. C. Nelson

R. E. Nightingale

C. R. Palmer (6)

A. M. Platt

J. A. Powe 11

R. E. Rhoads

J. V. Robinson

C. M. Unruh

H. H. Van Tuy 1

R. D. Widrig

L. D. Williams

Technical Information (5)

Publishing Coordination $\mathrm{CO}(2)$ 